\title{
Degradation and Recovery of Vegetation on Kaho'olawe Island, Hawai'i: A Photographic Journey ${ }^{1}$
}

\author{
Steven D. Warren ${ }^{2}$
}

\begin{abstract}
Over the past five centuries, the Hawaiian island of Kaho'olawe has suffered the ravages of slash-and-burn agriculture, interisland warfare, severe overgrazing by domestic and feral livestock, and military training. During the 1930s, Bishop Museum personnel photographed portions of Kaho'olawe and documented the degraded condition of the island. Many of the same locations were photographed during the early 1990s. Paired comparisons of the photographs illustrate a remarkable recovery of the vegetation on the island. The recovery is attributable to early introductions of plant species for livestock forage, followed by eradication of the livestock, and more recent erosion control and revegetation efforts. Barring renewal of environmentally deleterious activities, the outlook for Kaho'olawe is promising.
\end{abstract}

KaHo'olawe, SMALLEST of the eight major islands of the Hawaiian Archipelago, measures about $17.7 \mathrm{~km}$ long by $10.5 \mathrm{~km}$ wide and comprises some 11,340 ha. The island lies in the rain shadow of Haleakalā Volcano on Maui. Climatic records for the island are scant, but estimated annual precipitation is approximately $370-500 \mathrm{~mm}$ (Department of the Navy 1979, Ziegler and Giambelluca 1998), with most of it falling from November through March. In addition to the low precipitation, Kaho'olawe is the windiest of the Hawaiian Islands (Stearns 1940). Deflected by Haleakalā, the persistent northeasterly trade winds accelerate across the intervening channel, reaching an average speed of about $9 \mathrm{~m} \mathrm{sec}^{-1}$ at Kaho'olawe (Department of Geography, University of Hawaii 1973).

Much of Kaho'olawe may have been covered at one time with a dryland scrub forest similar to remnants of that vegetation type currently found on the 'Ewa Plain

\footnotetext{
${ }^{1}$ Funding provided by the Naval Facilities Engineering Command, Pacific Division. Manuscript accepted 20 October 2003.

${ }^{2}$ Center for Environmental Management of Military Lands, Colorado State University, Fort Collins, Colorado 80523-1490.
}

Pacific Science (2004), vol. 58, no. 3:461-495

(C) 2004 by University of Hawai'i Press

All rights reserved of O'ahu and the Kawaihae-Waimea area of Hawai'i (Cuddihy and Stone 1990). Today, however, approximately a third of the island is a barren hardpan; the remainder is dominated by the introduced shrub kiawe (Prosopis pallida) and a variety of introduced grasses and forbs. The disturbance of native vegetation on Kaho'olawe probably began with slash-and-burn agriculture practiced by sixteenth-century Hawaiians (Kirch 1982). Intense interisland warfare before the arrival of European explorers left the island "... nearly overrun with weeds, and exhausted ... of inhabitants ..." (Vancouver 1798). The human population declined from an estimated peak of 800 around A.D. 1500 to approximately 60 at the time of European discovery (Hommon 1980), presumably in response to a depleted natural resource base. In 1779 the crew of Captain Cook described the island as "barren," "desolate," and an "altogether poor island" (Beaglehole 1967).

The same explorers that lamented the poor condition of the island unwittingly contributed to its further demise. Early visitors introduced goats to the Hawaiian Islands as gifts to the native monarchy near the end of the eighteenth century. Some of the goats were likely placed on Kaho'olawe (Sunday Advertiser 1912). Although numerous visits were made to Kaho'olawe over the next half century, the presence of goats was not actually recorded until 1850 (Perkins 1854). It is, 
therefore, difficult to discern the presence, abundance, or effect of the animals before that time. Perkins characterized the island as "desolate in the extreme; the reddish, sterile soil being unrelieved by either tree or shrub." Despite the description, some trees and shrubs were present; Perkins described a grove of "akokoa shrubs" (Chamaesyce spp.) and a few stunted wiliwili trees (Erythrina sandwicensis), many of the former having died evidently after being stripped of bark by goats. Some sizeable expanses of grassland were also present, at least on the lower slopes. Perkins mentioned that he and his companions set fire to the grass as a signal to others in their party and that the fire burned for nearly a week, serving as a beacon to passing ships. For a more complete treatment of the early vegetation on Kaho'olawe see Mueller-Dombois and Fosberg (1998).

In 1858, William F. Allen sighted and killed a single goat, although he speculated that there were considerably more (Allen 1858). Allen reported to R. C. Wyllie, Minister of Foreign Affairs for the Kingdom of Hawai' $i$ and co-owner of a 20-yr lease of Kaho'olawe, that the island could support 20,000 sheep. A year later over 2,000 sheep had been placed on the island (Lomax 1940), beginning a series of ill-fated ranching enterprises. By 1875 , there were approximately 20,000 sheep and several hundred goats present (Ka Lahui Hawaii 1875). Six years later, cattle were introduced (Hawaiian Gazette 1881), and in 1884 there were about 9,000 goats, 2,000 sheep, 200 cattle, and 40 horses on the island (Bagot 1884).

It is probable that extensive wind erosion of the higher portions of Kaho'olawe was occurring before the ranching industry began. In 1841, survivors of a shipwreck reported sinking ankle deep in the soil on the south part of the island (Wilkes 1845), the area most likely to receive windblown deposits from the higher reaches of Kaho'olawe. Specific mention of severe wind erosion, however, was not made until 1880 (Bowser 1880), when reports were made of red clouds of dust being blown 30-40 miles [48-64 km] out to sea. To protect the limited remaining resources, the island was declared a Forest Re- serve in 1910 (Hosmer 1910a). Numerous forays were organized over the next $8 \mathrm{yr}$ to eradicate the livestock, but the goats and sheep persisted. There were also unsuccessful attempts to reestablish woody vegetation (Hawaiian Gazette 1918a).

By 1918, the economic demand for Kaho'olawe as a cattle ranch, coupled with the failed attempts to eradicate the goats, unsuccessful reestablishment of trees, and the lack of funds to continue the effort, led the governor to withdraw Kaho'olawe from the Forest Reserve (Hawaiian Gazette 1918b). Cattle were reintroduced that year under the terms of a lease requiring the elimination of the goat population and steps toward reforestation. Over the next two decades, thousands of native and introduced tree seedlings were planted (Ashdown 1979) but with only limited success (Rice et al. 1932). In addition, several tons of native and introduced grass and forb seeds were planted (Ashdown 1979). Over 13,000 goats were either removed or destroyed. Despite the efforts, the goats persisted in small numbers and great clouds of eroded dust continued to blow off the island (Judd 1938).

Such were the conditions in February 1931 when E. H. Bryan and J. Gilbert McAllister of the Bishop Museum in Honolulu visited Kaho'olawe. McAllister, an archaeologist, took numerous photographs of archaeological features on the island, two of which were published in 1933 (McAllister 1933). Bryan took photographs of the island in 1931 and again in January 1939, although his subject matter was more physiographic in nature. The photographs are archived at the Bishop Museum.

With the entrance of the United States into World War II in 1941, Kaho'olawe was acquired by the U.S. military and became a target for offshore gunnery, amphibious assaults, and aerial bombing practice. Over the next half century the island was used by every branch of the U.S. armed services. Training on Kaho'olawe factored into virtually every large-scale military conflict in which the U.S. military was involved from World War II until the time the island was returned to the State of Hawai'i in May 1994. 


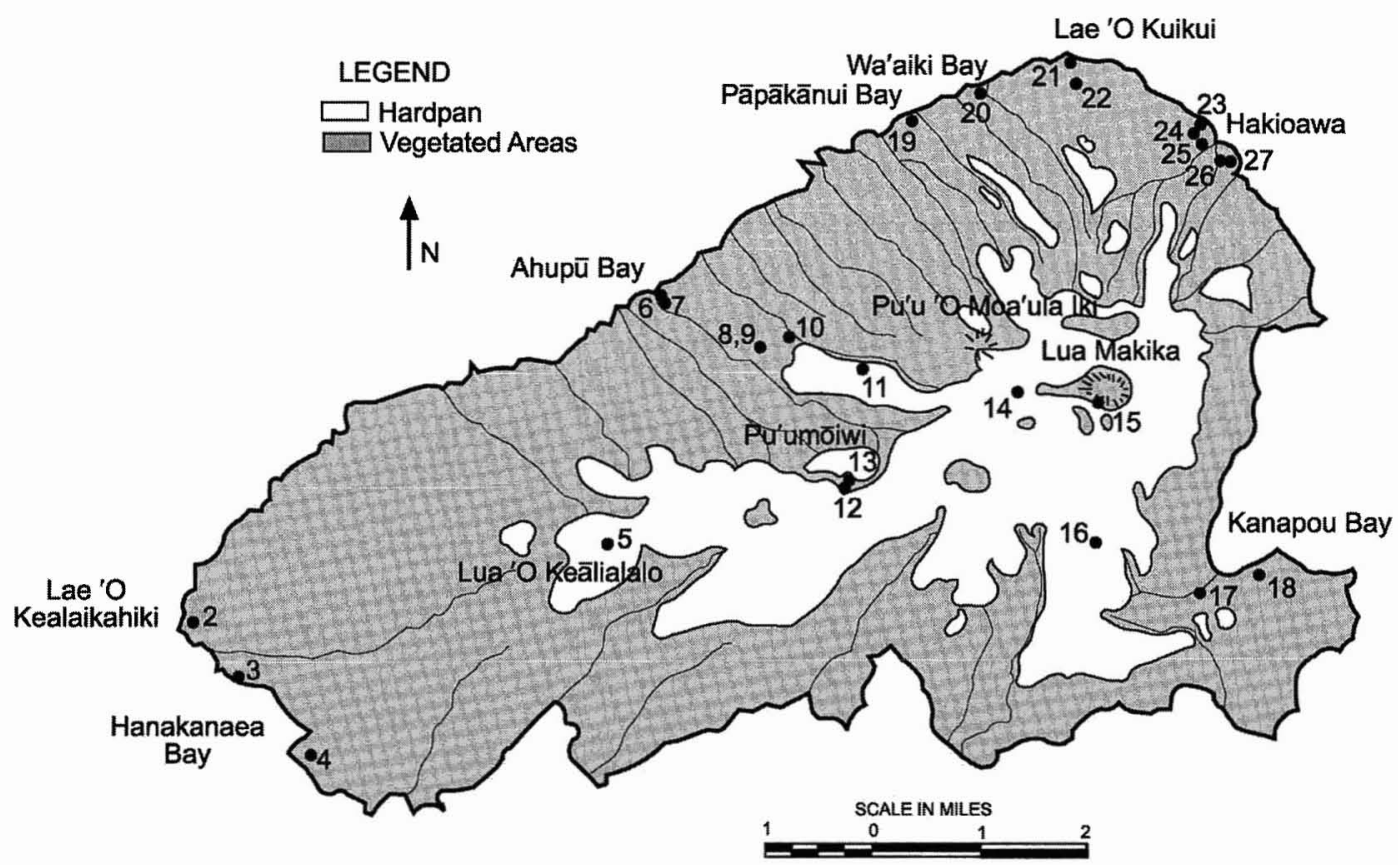

Figure 1. Locations from which the paired photographs were taken. Numbers correspond to the respective figure numbers in this paper.

\section{MATERIALS AND METHODS}

Near the end of the military tenure on Kaho'olawe, I was involved in a revegetation project on the island. As part of that effort, a survey was made of information regarding the original vegetation on Kaho'olawe and historic records of alien plant introductions. During a visit to the Bishop Museum archives, the Bryan and McAllister photograph collection was discovered. Forty-four photographs offered sufficient panorama of the $\mathrm{Ka}$ ho'olawe landscape to lend insight into the condition of the island in the 1930s. During subsequent excursions to Kaho'olawe in 1991 and 1993, an attempt was made to identify the precise location of each of the original photographs in hopes of rephotographing the locations to document changes in the vegetation.

\section{RESULTS}

Of the 44 candidate photographs from the 1930 s, 29 locations were successfully re- located and rephotographed. Three of the locations provided redundant views. Hence, only 26 paired photographs are included here. The locations from where the original Bryan and McAllister photographs were taken are shown on a map of the island (Figure 1). Paired comparisons of scenes from the 1930s and 1990s are presented in Figures $2-27$. They provide a photographic essay of changes in the landscape and vegetation of Kaho'olawe during the intervening period. Although there are approximately 160 alien plant species known to occur on Kaho'olawe (Warren et al. 1994), the era of introduction can be definitively established for only 49. Tables 1-3 provide a record of alien plant introductions predating the ranching era, during the ranching era, and during postranching rehabilitation efforts, respectively.

\section{DISCUSSION}

The most striking difference between scenes in the 1930s and 1990s is the vast increase in 


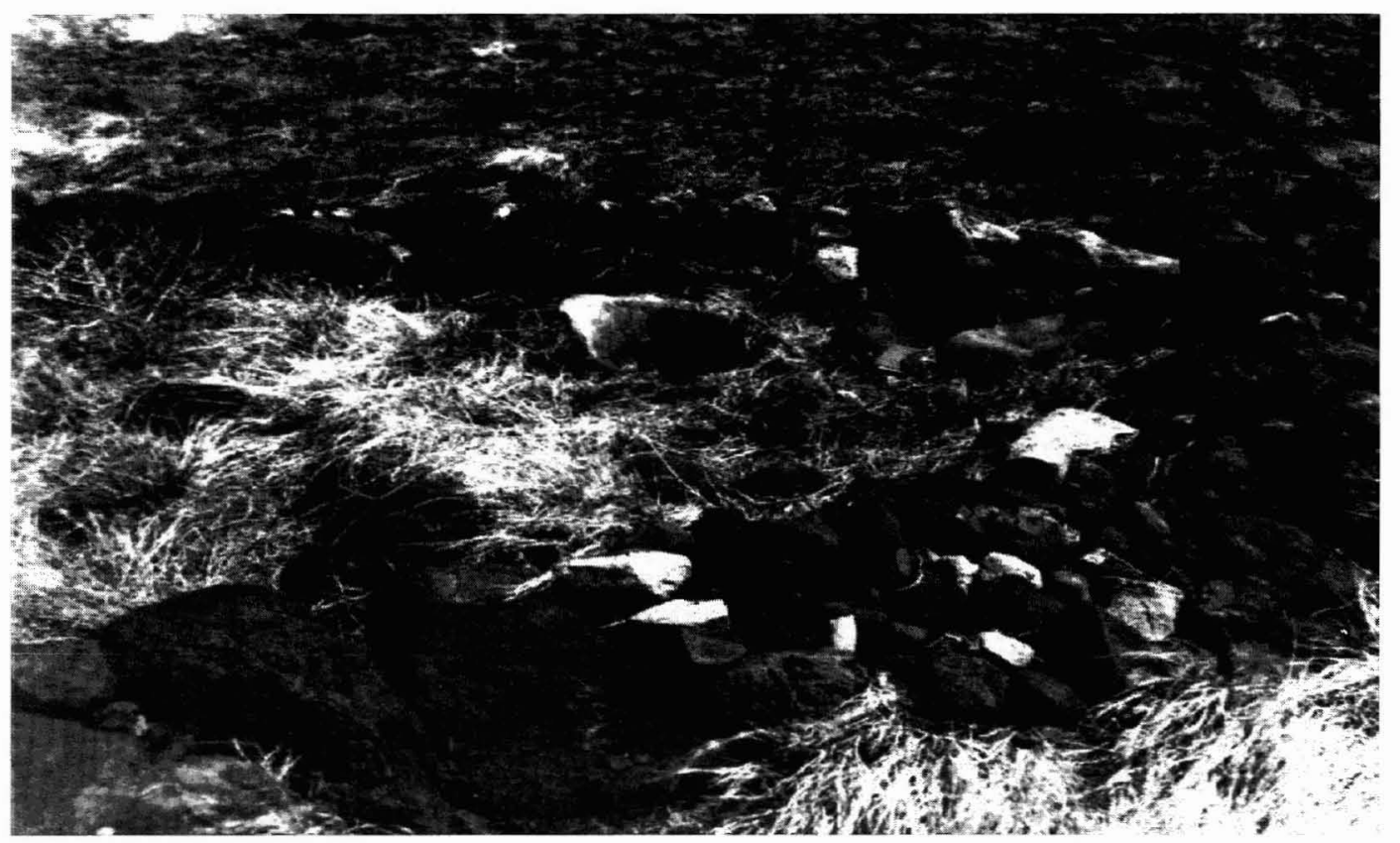

FigUre $2 a$. "Ko'a at Lae o Kealaikahiki with ... water-worn up-right stone at center back," J. G. McAllister, 1931, Bishop Museum negative no. 15500.

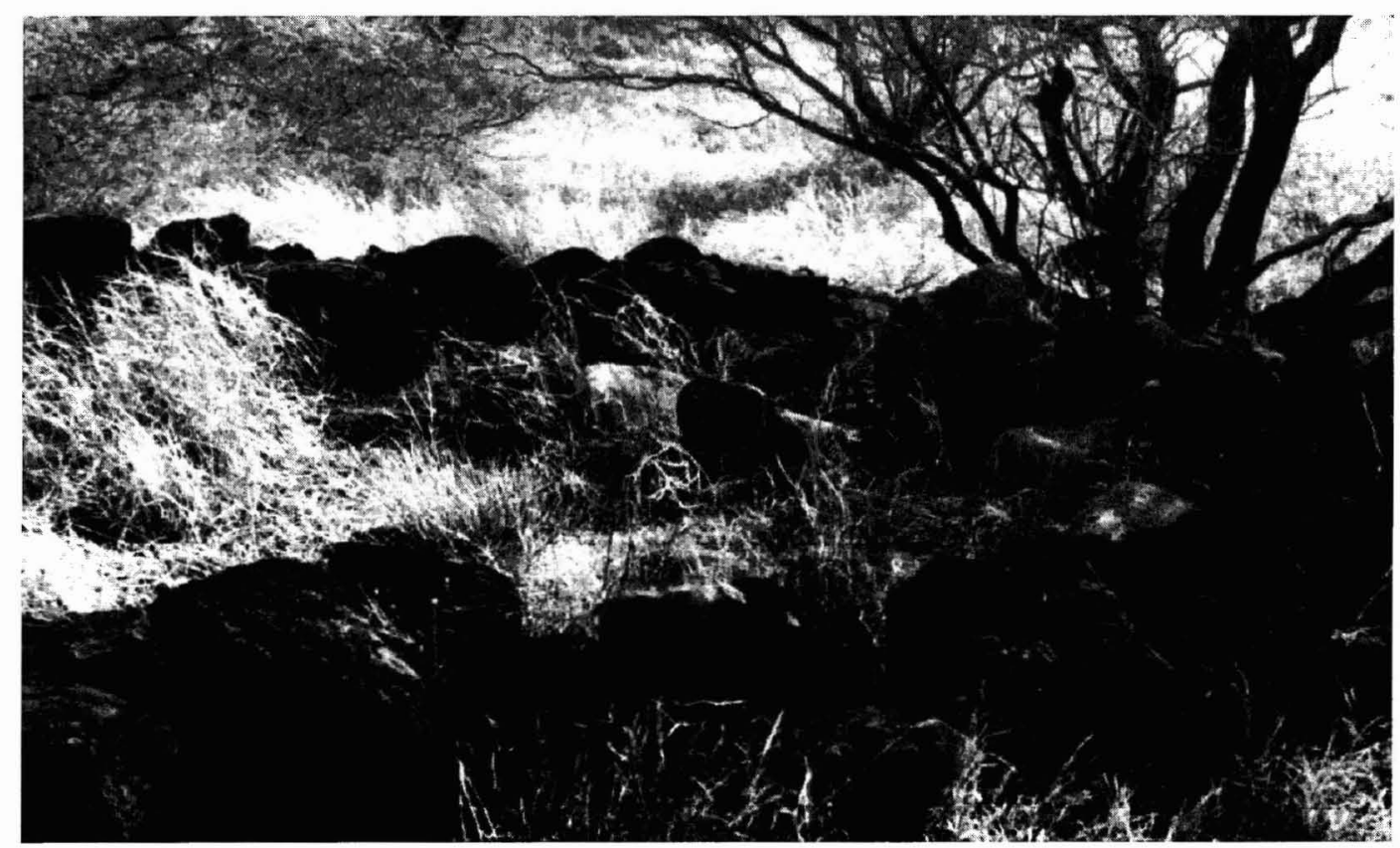

FIGURE 2b. Same location, 1991. The water-worn, upright stone is still present. Note the dense growth of grass and kiawe in the background. 


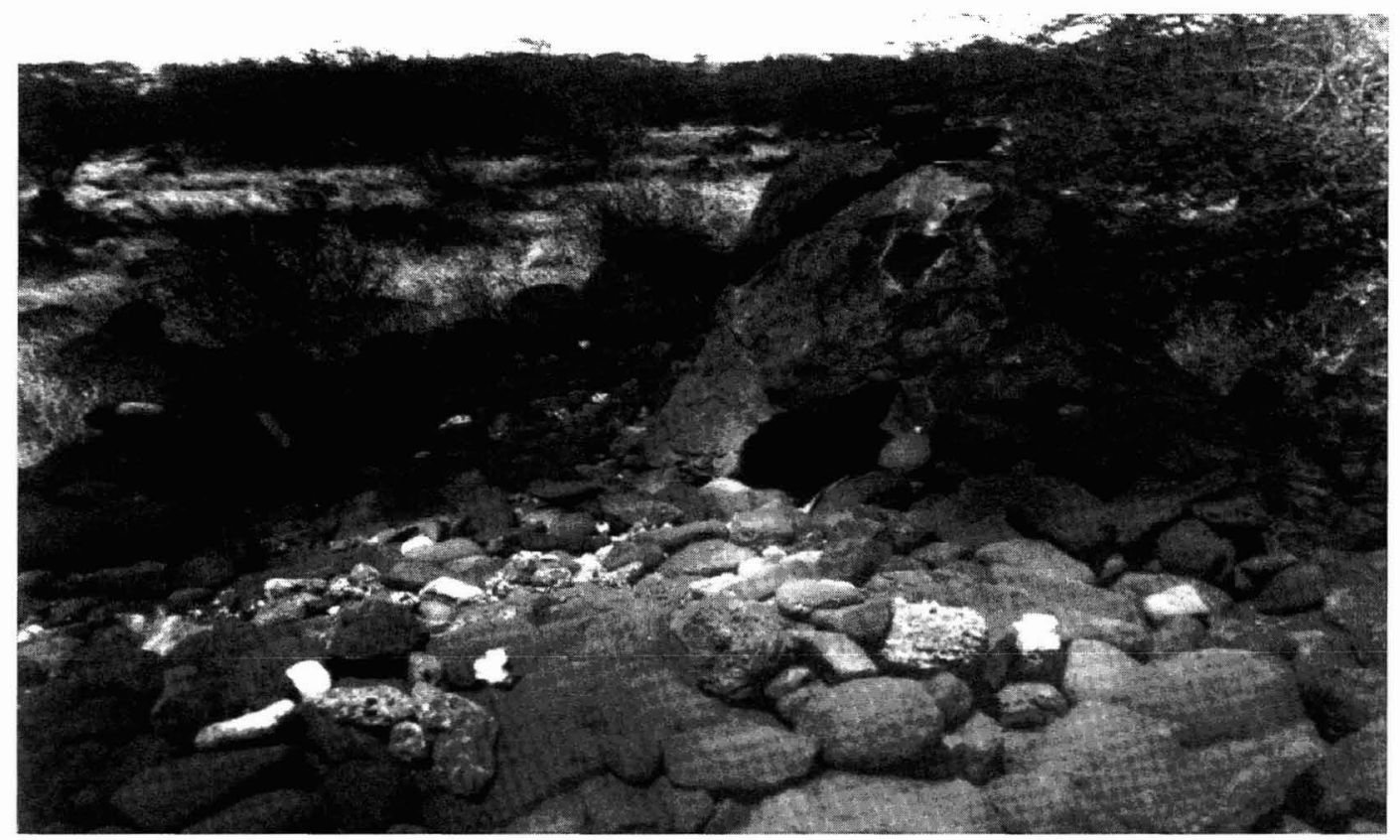

FigURE 3a. "Ko'a northwest of Hanakanaea Bay, with large hollow stone 5 feet $[1.5 \mathrm{~m}]$ high at the center back," J. G. McAllister, 1931, Bishop Museum negative no. 15497. The photograph is very similar to another taken by McAllister, 1931, Bishop Museum negative no. 15498, which is not included here.

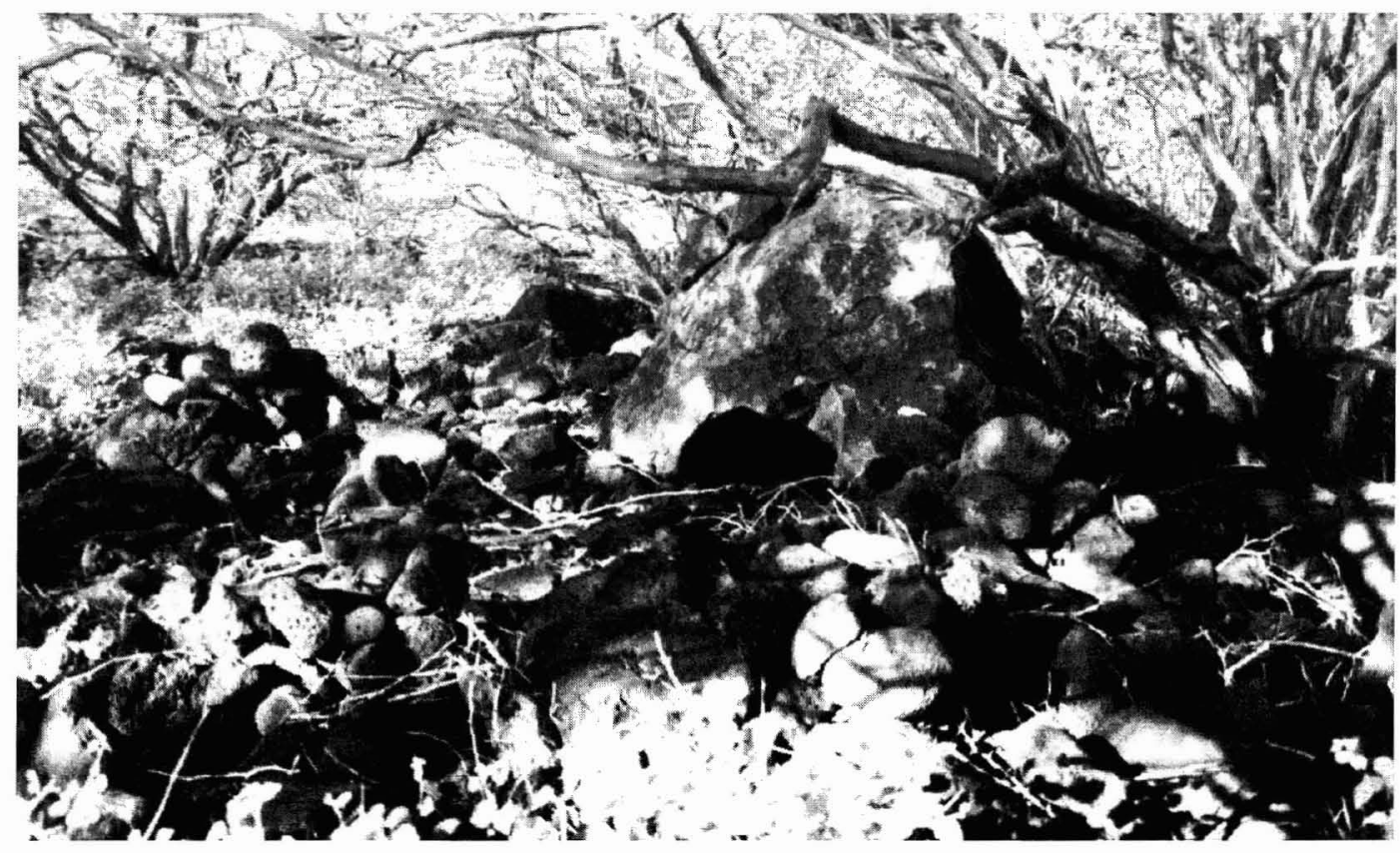

FIGURE 3b. Same location, 1991. Note the broadleaf 'ilima that is now abundant in the foreground. 


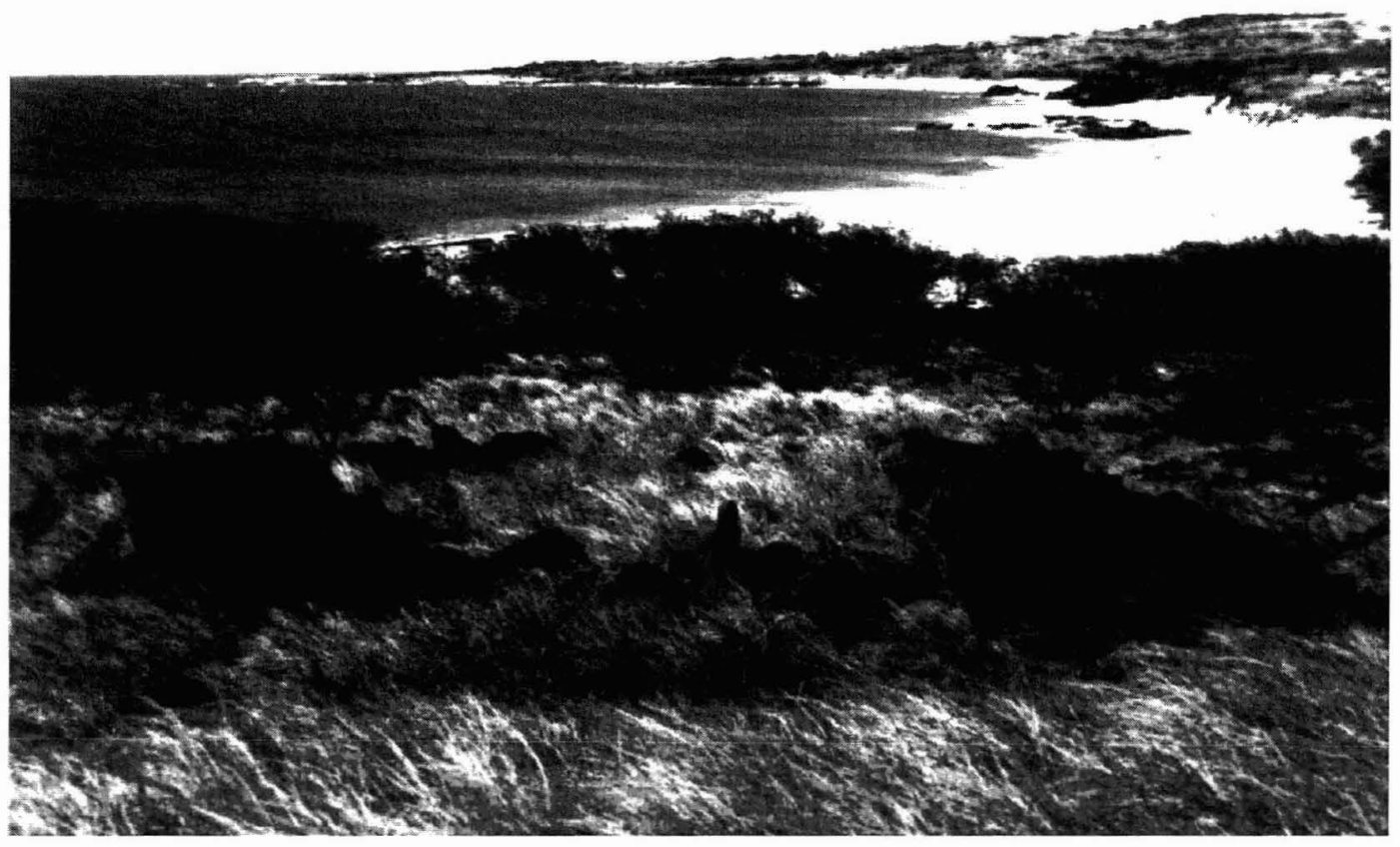

Figure 4a. "Ko'a on east side of Hanakanaea Bay, with the top of the upright stone visible above the wall," J. G. McAllister, 1931, Bishop Museum negative no. 15492. The photograph is very similar to one taken by E. H. Bryan, 1931, Bishop Museum negative no. 16600, which is not included here. Bryan labeled his photograph "Hanakanaea Bay, called 'Smugglers Cove', looking north toward Kealaikahiki. Legendary point of departure for voyagers to Society Islands."

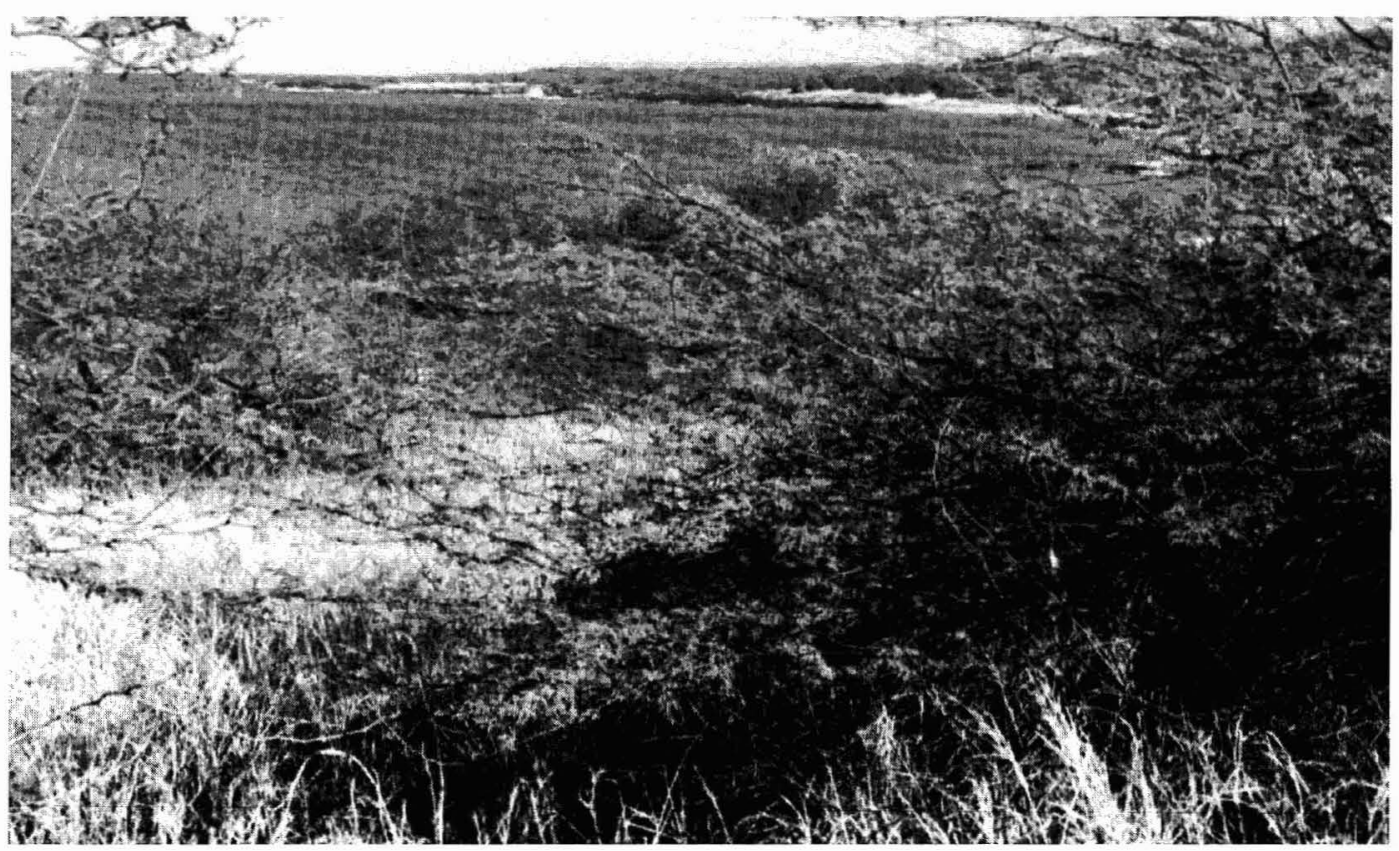

Figure 4b. Same location, 1991. The stone wall and much of the beach are obscured by dense growth of kiawe. A cluster of military buildings in the upper right is likewise obscured by kiawe. 


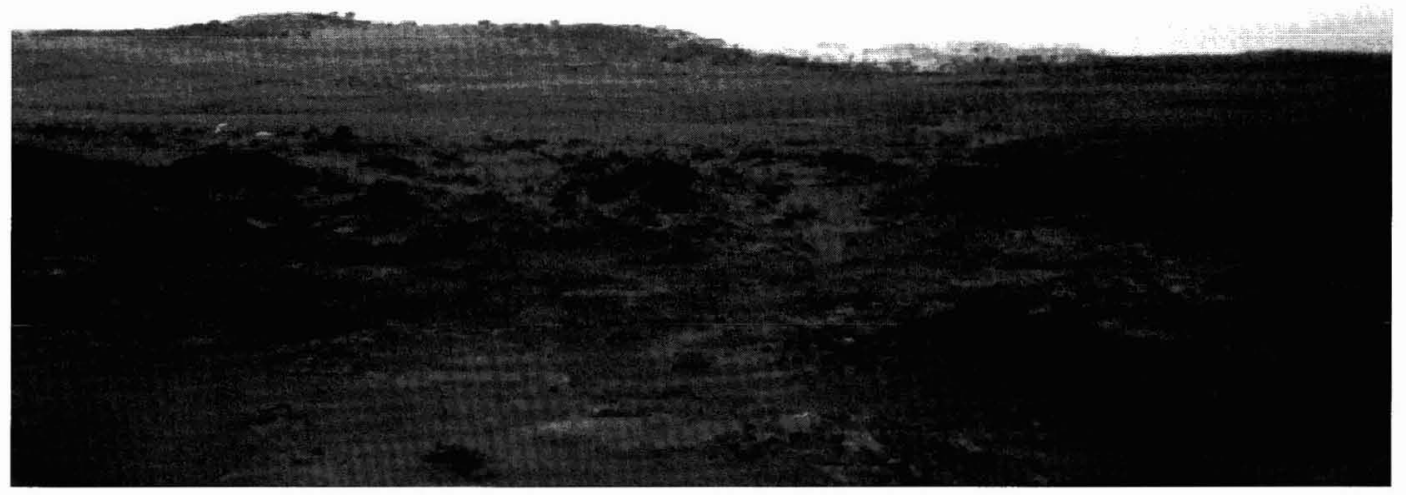

FIgURE 5a. "Looking southwest from south side of Lua Kealialalo, elevation 840 feet [255 m]. Algaroba growth at crater,” E. H. Bryan, 1931, Bishop Museum negative no. 16603. Algaroba is another name for kiawe.

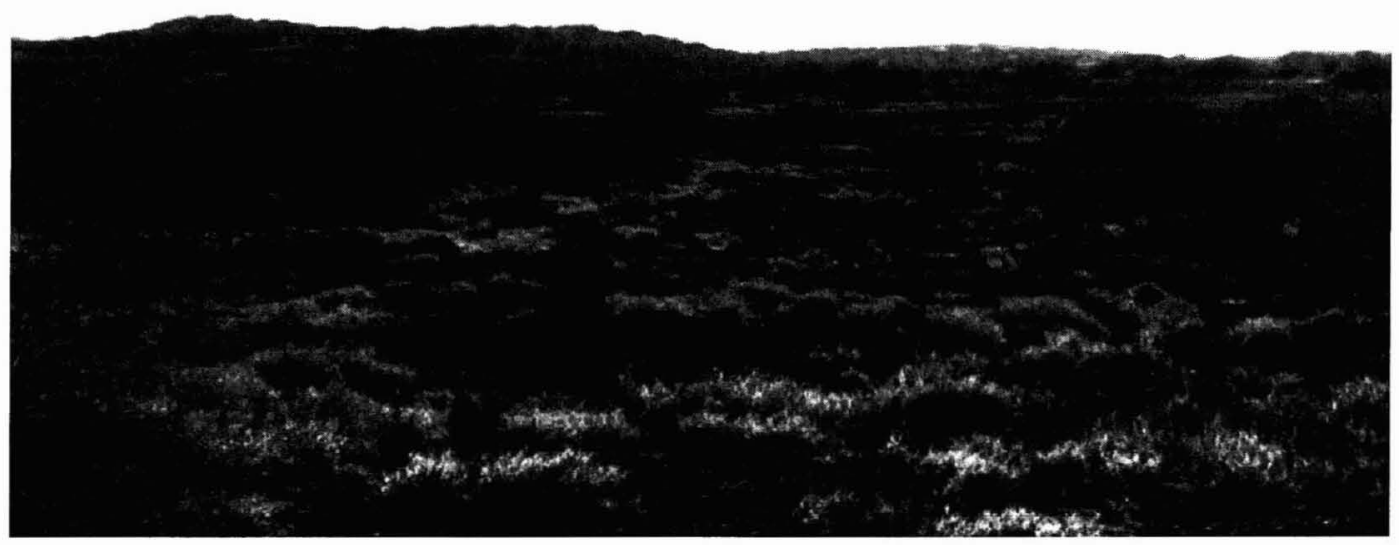

FIgURE 5b. Same location, 1991. The small hill in the background is Lua 'O Keaualalo. Note the increase in grass and kiawe. Barrels marking a former military target area are visible in the right center portion of the photograph. 


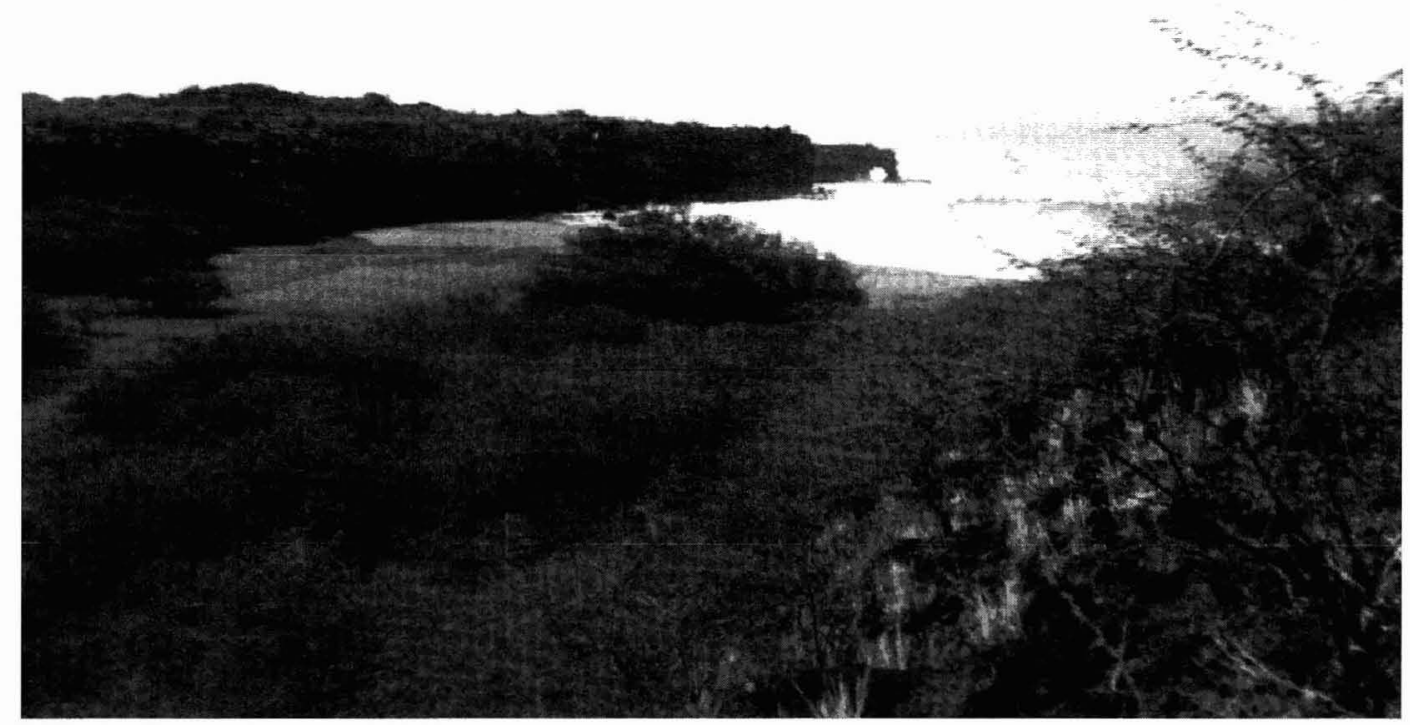

Figure 6a. "Mouth of Ahupu Gulch, looking west northwest," E. H. Bryan Jr., 1939, Bishop Museum negative no. 19829.

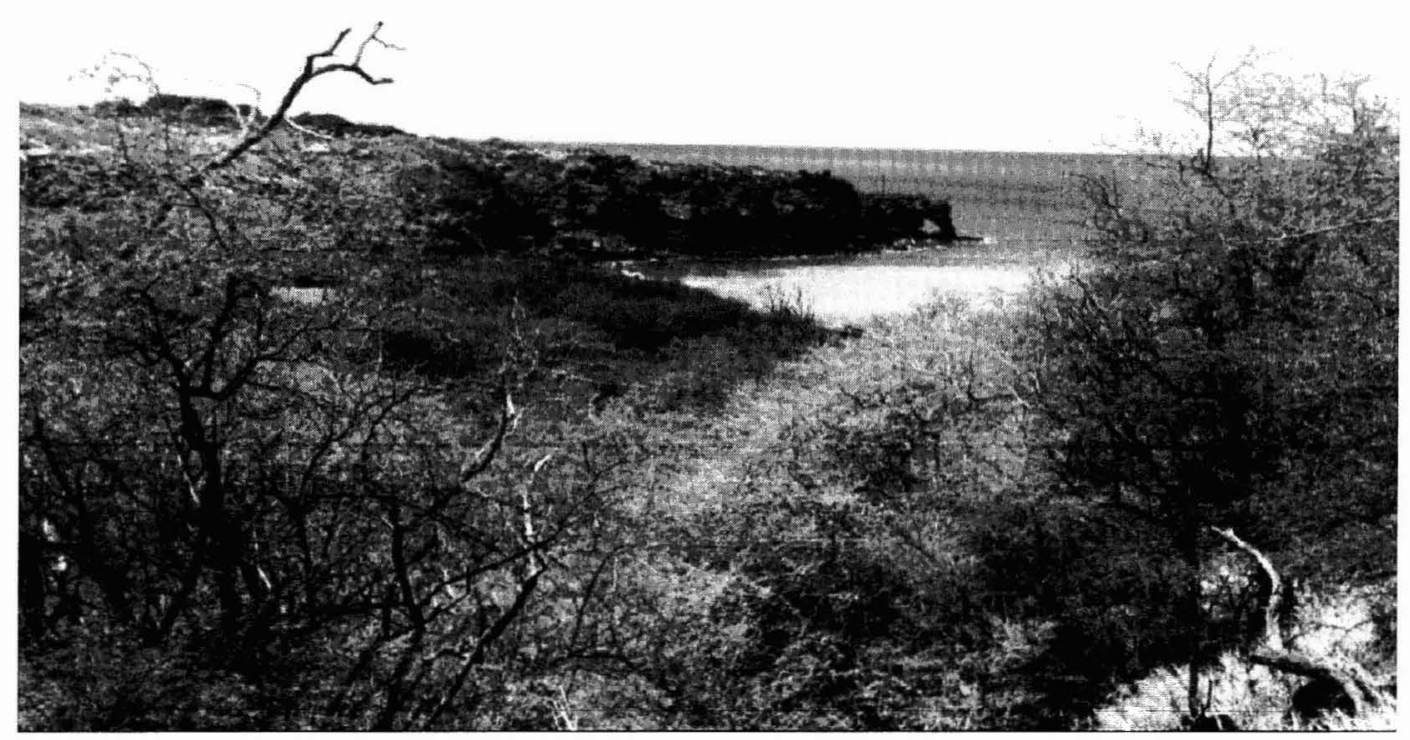

FIgURE 6b. Same location, 1991. Kiawe has further invaded the beach and the hillslope from where the photograph was taken. 


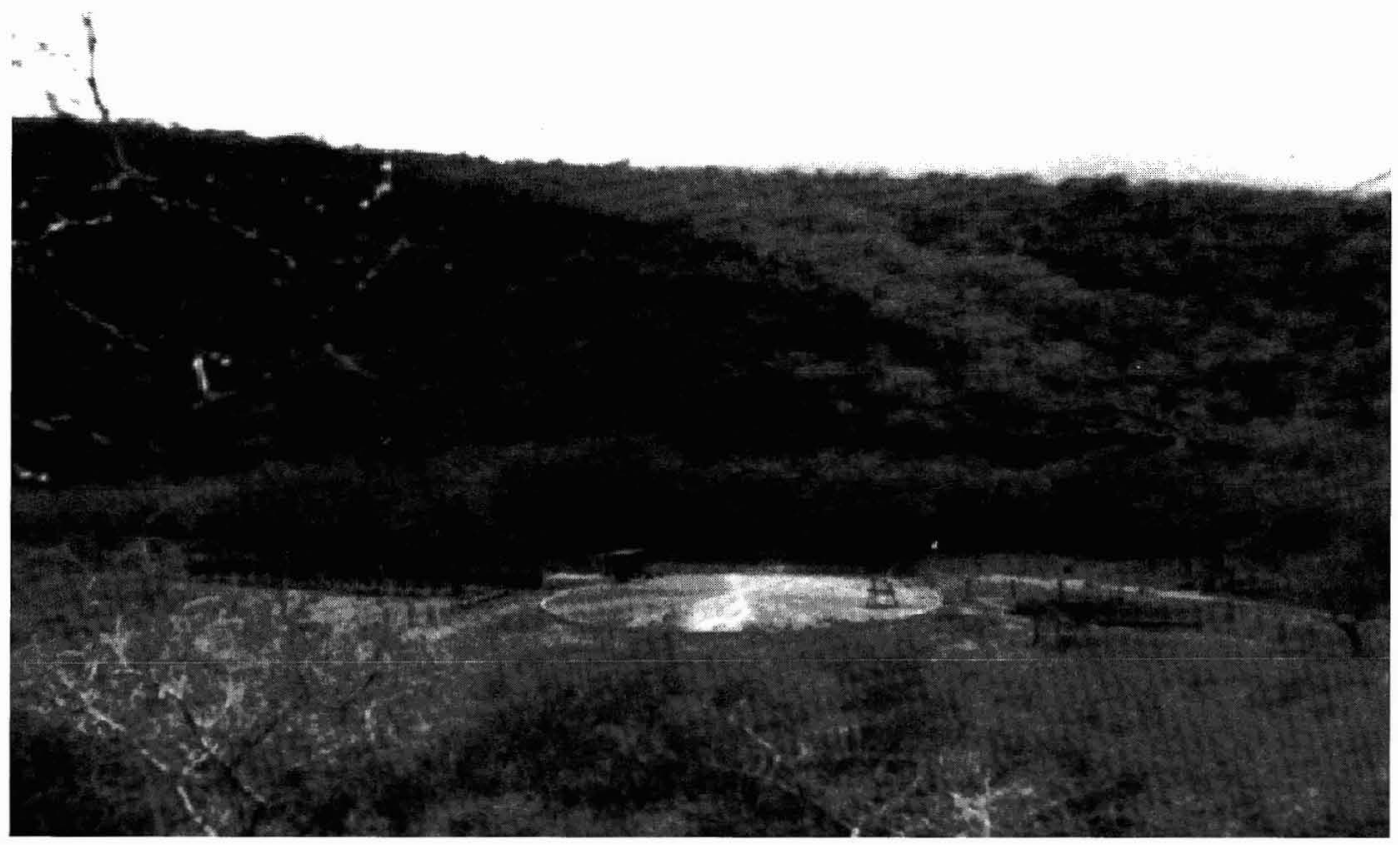

FIGURE 7a. "Cistern in Ahupu Gulch looking west southwest," E. H. Bryan Jr., 1939, Bishop Museum negative no. 19830.

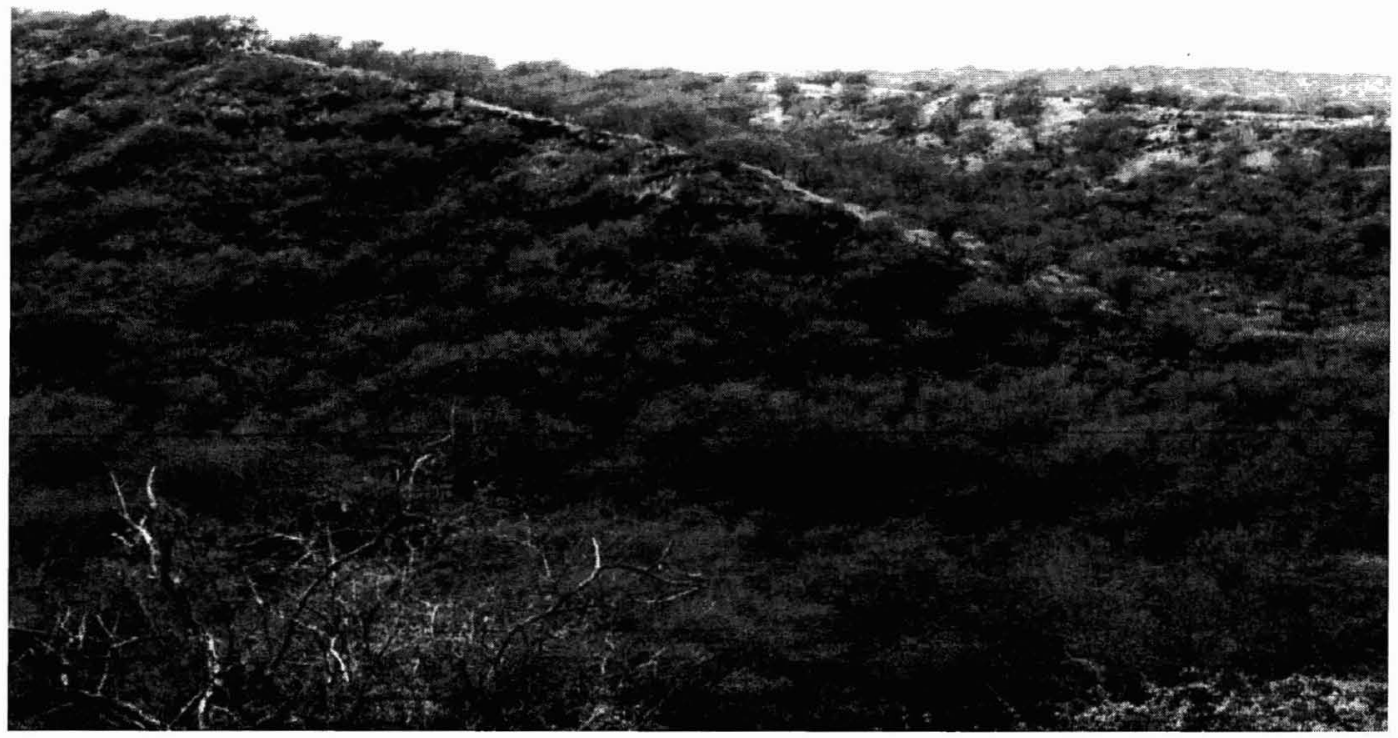

FIGURE $7 b$. Same location, 1991. The cistern and wooden slough are still present although in a state of considerable decay. Both are obscured in the 1991 photograph by dense kiawe. 


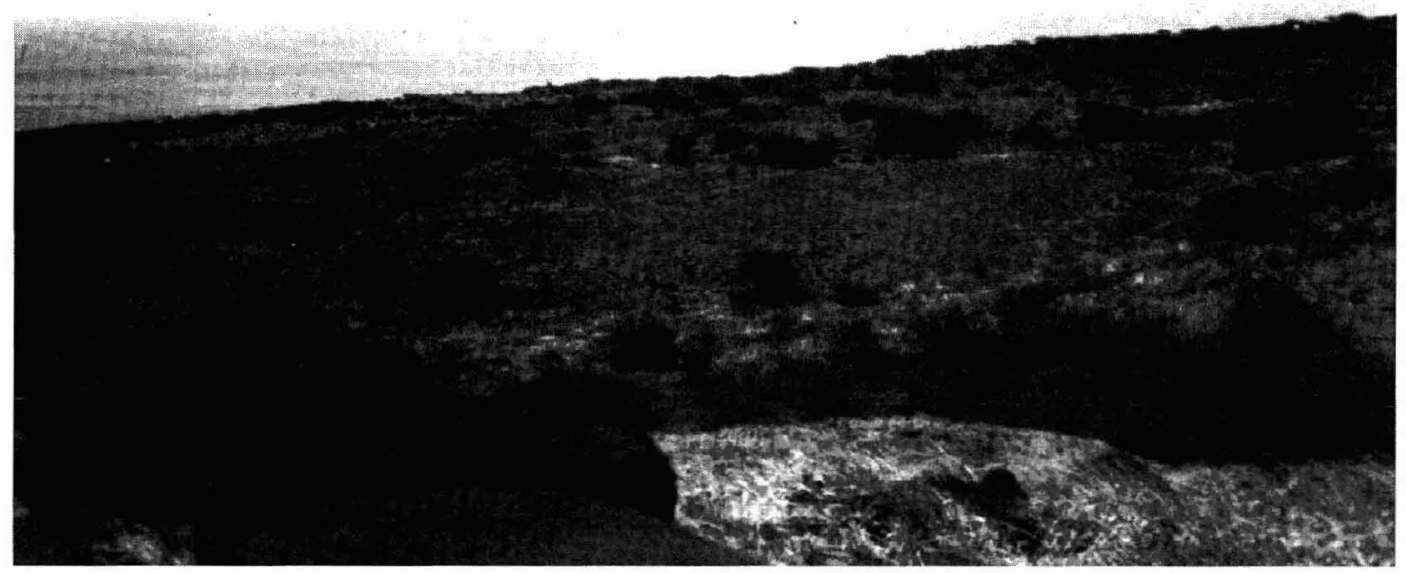

FigURE 8a. "Looking north from triangulation station 'aid'," J. G. McAllister, 1931, Bishop Museum negative no. 15505. The west end of Maui is visible in the background. Two cows appear as dark specks in the center of the photograph.

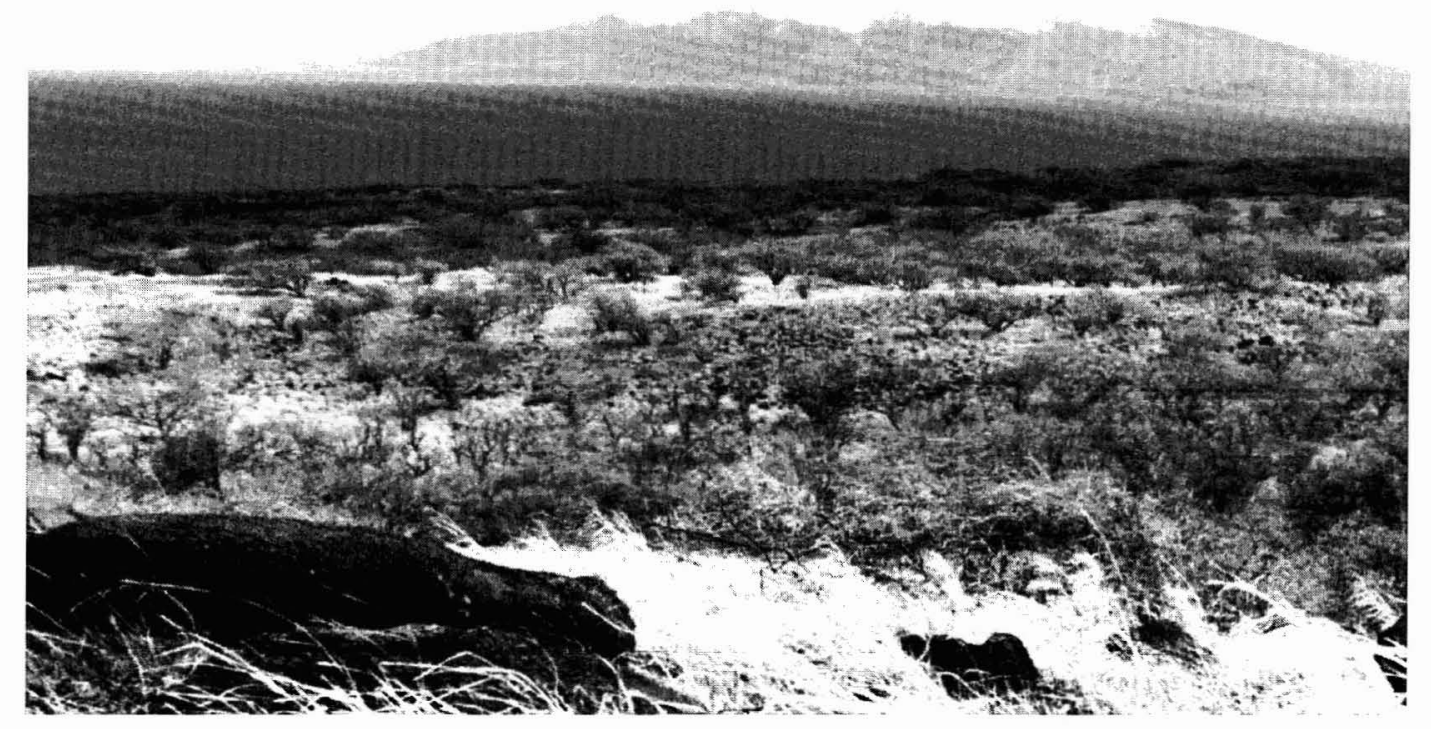

FigURE 8b. Same location, 1993. Note the increase in grass (species unknown) and kiawe. 


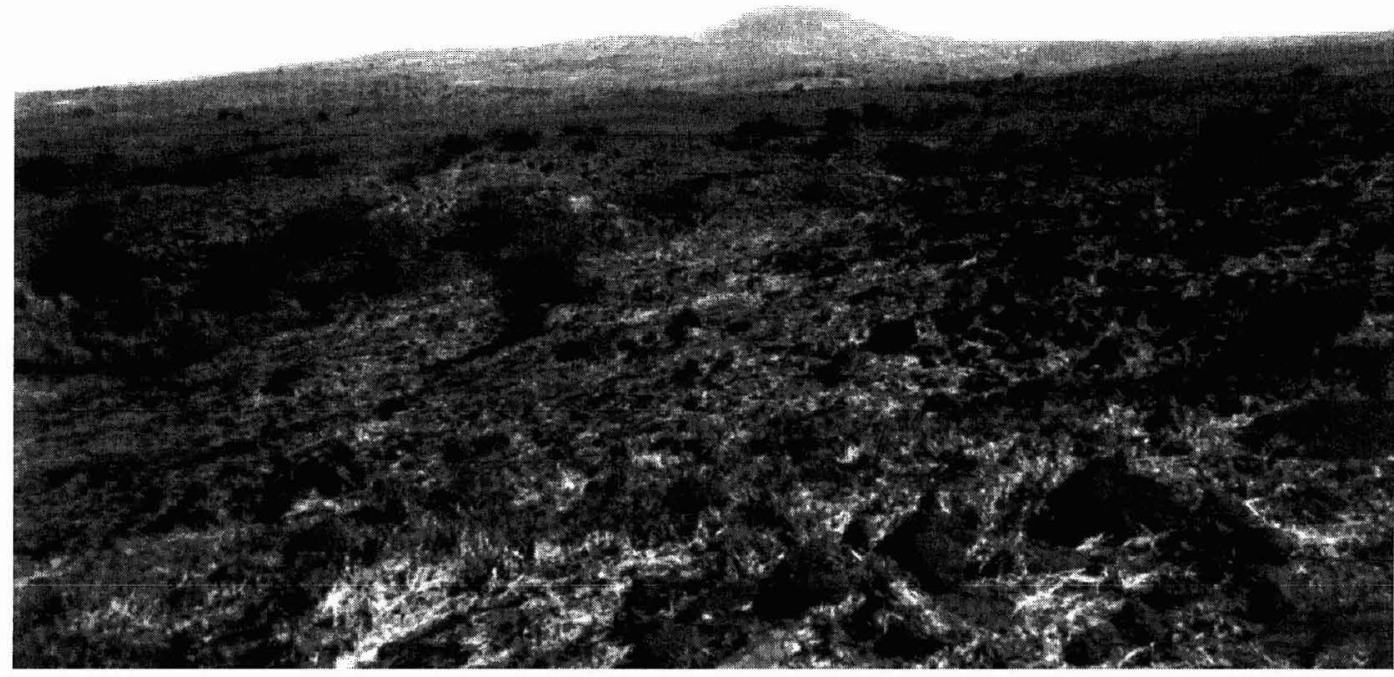

FIGURE 9a. "Showing land west of Maula (sic), which is the elevation in the background. Taken from triangulation station 'aid'," J. G. McAllister, 1931, Bishop Museum negative no. 15504. This view is almost identical to Bishop Museum negative no. 16578 by E. H. Bryan, 1931, described as a "view of Moaula (sic), looking east across Kaukamoku Gulch. Pili grass and algaroba,-bare red dirt in distance.”

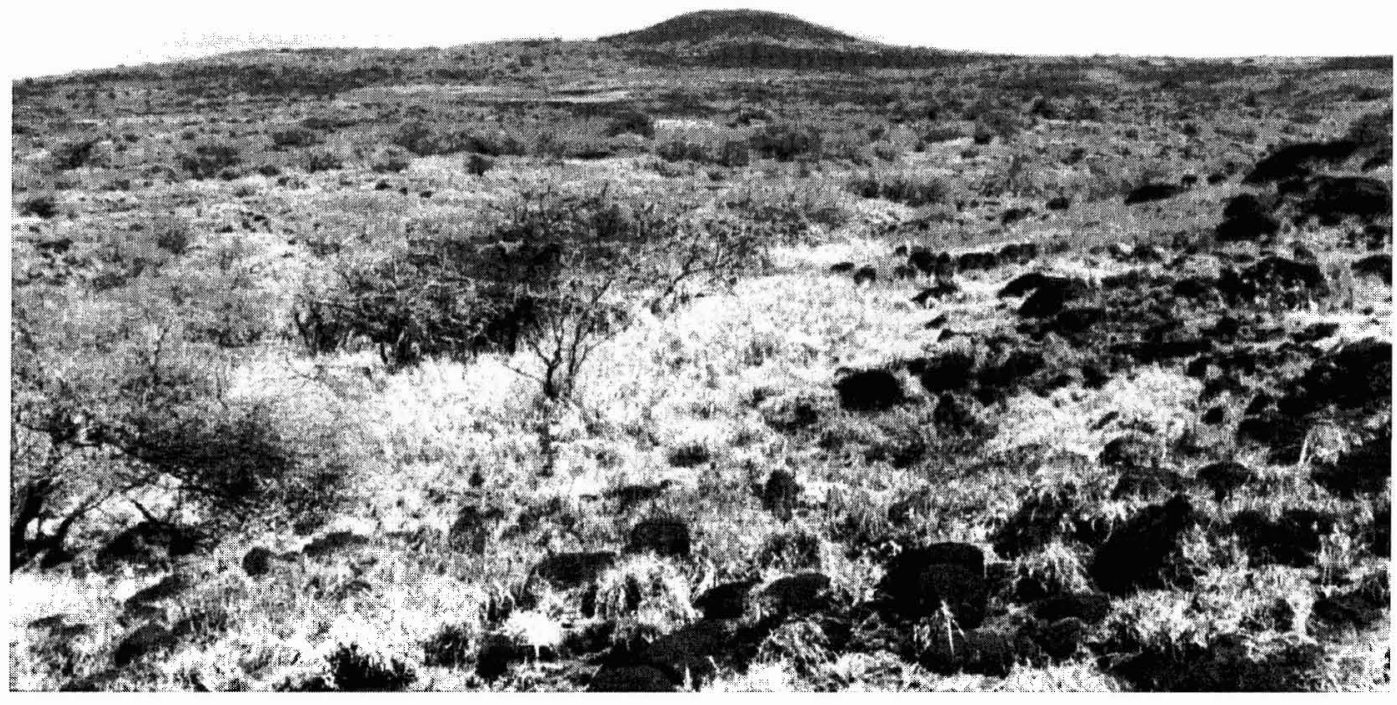

Figure $9 b$. Same location, 1991. The wooden beam barely visible at the bottom of the 1931 photograph is still present although it has been moved slightly and is not visible in the 1991 photograph. Note the increase of grass and kiawe in the foreground and background. Scarcely visible on the barren hardpan below $\mathrm{Pu}^{\prime} \mathrm{u}$ ' $\mathrm{O}$ Moa'ula is a circular military target composed of painted rocks or tires. 


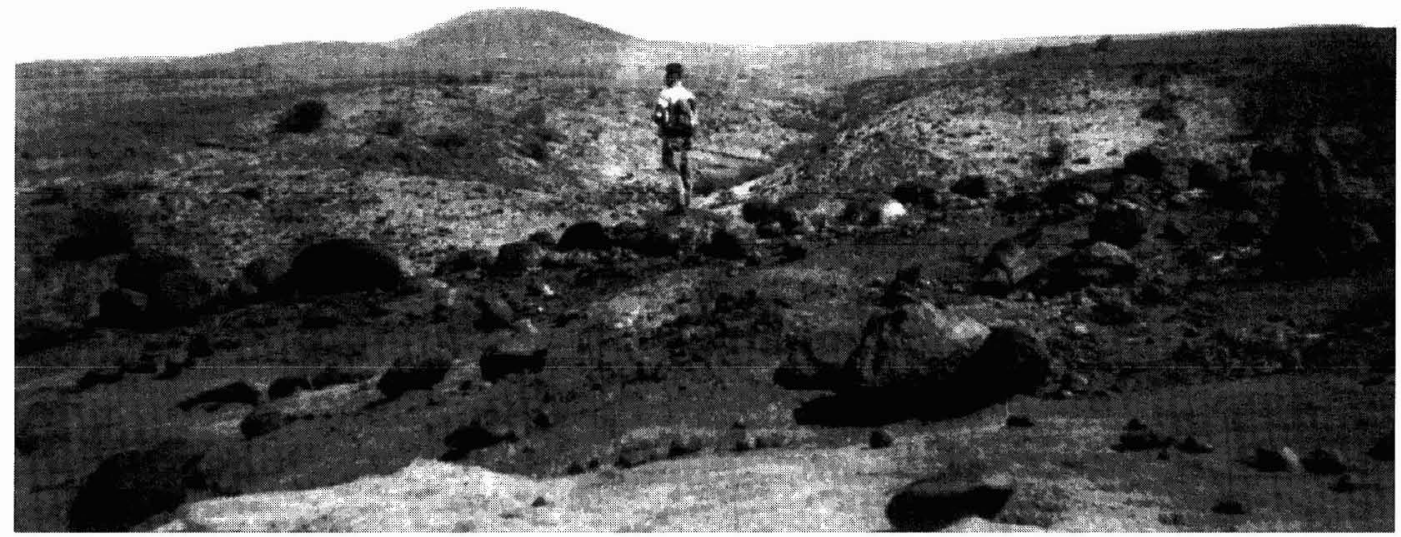

Figure 10a. "Looking across Kaukamoku Gulch towards Moaula (sic)," E. H. Bryan, 1931, Bishop Museum negative no. 16579 .

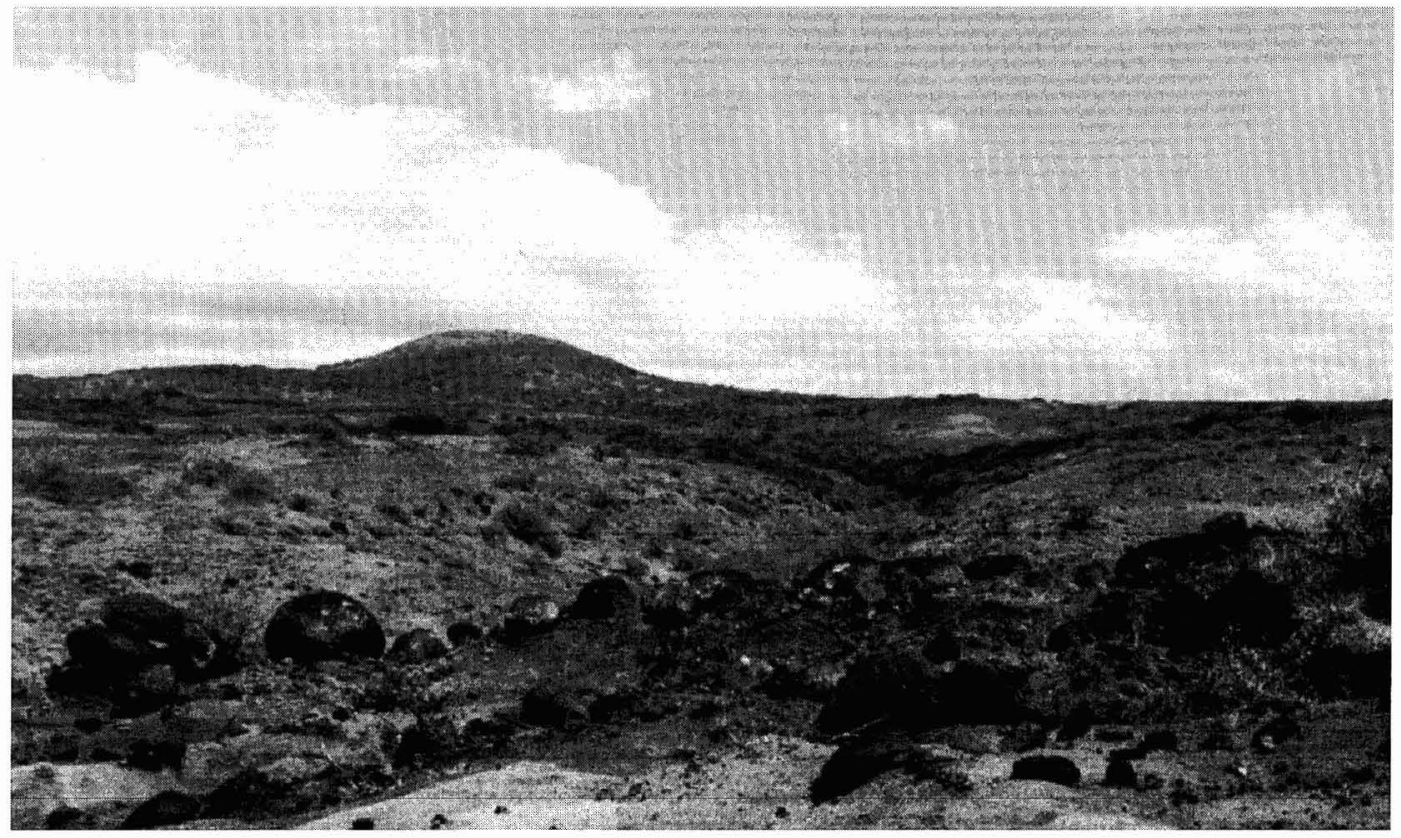

FigURE 10b. Same location, 1991. The upright, striated stone seen on the far right in the 1931 image has fallen, possibly indicating continued erosion. Note also the increase in vegetation. 


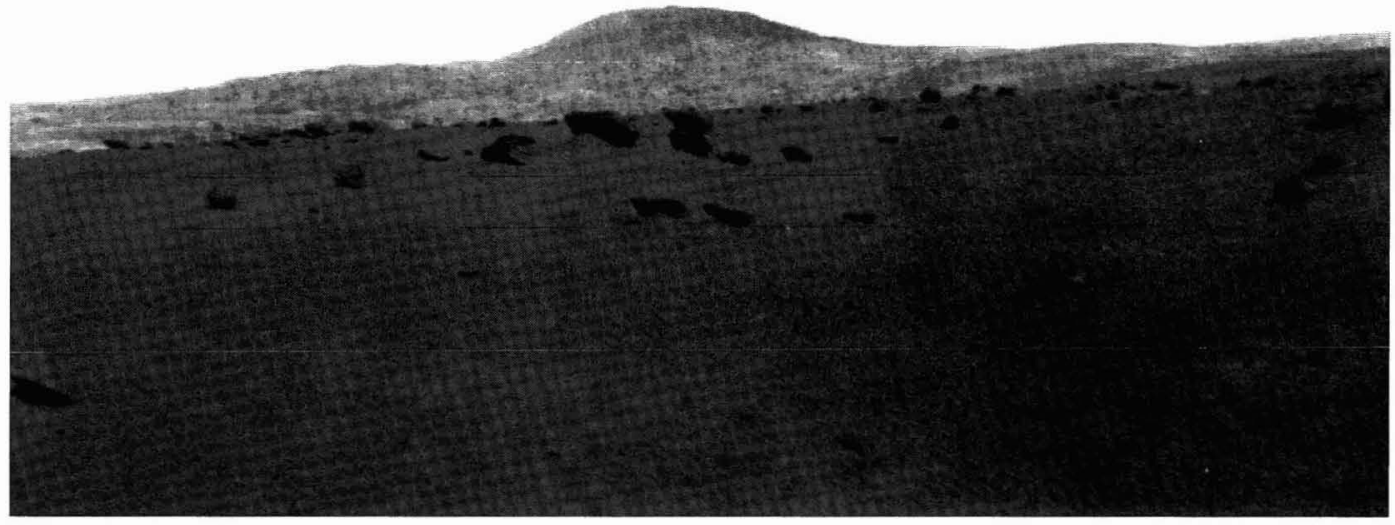

Figure 11a. "Central plateau, bare and wind-swept, showing cones of dirt in lee of rocks," E. H. Bryan, 1931, Bishop Museum negative no. 16580 .

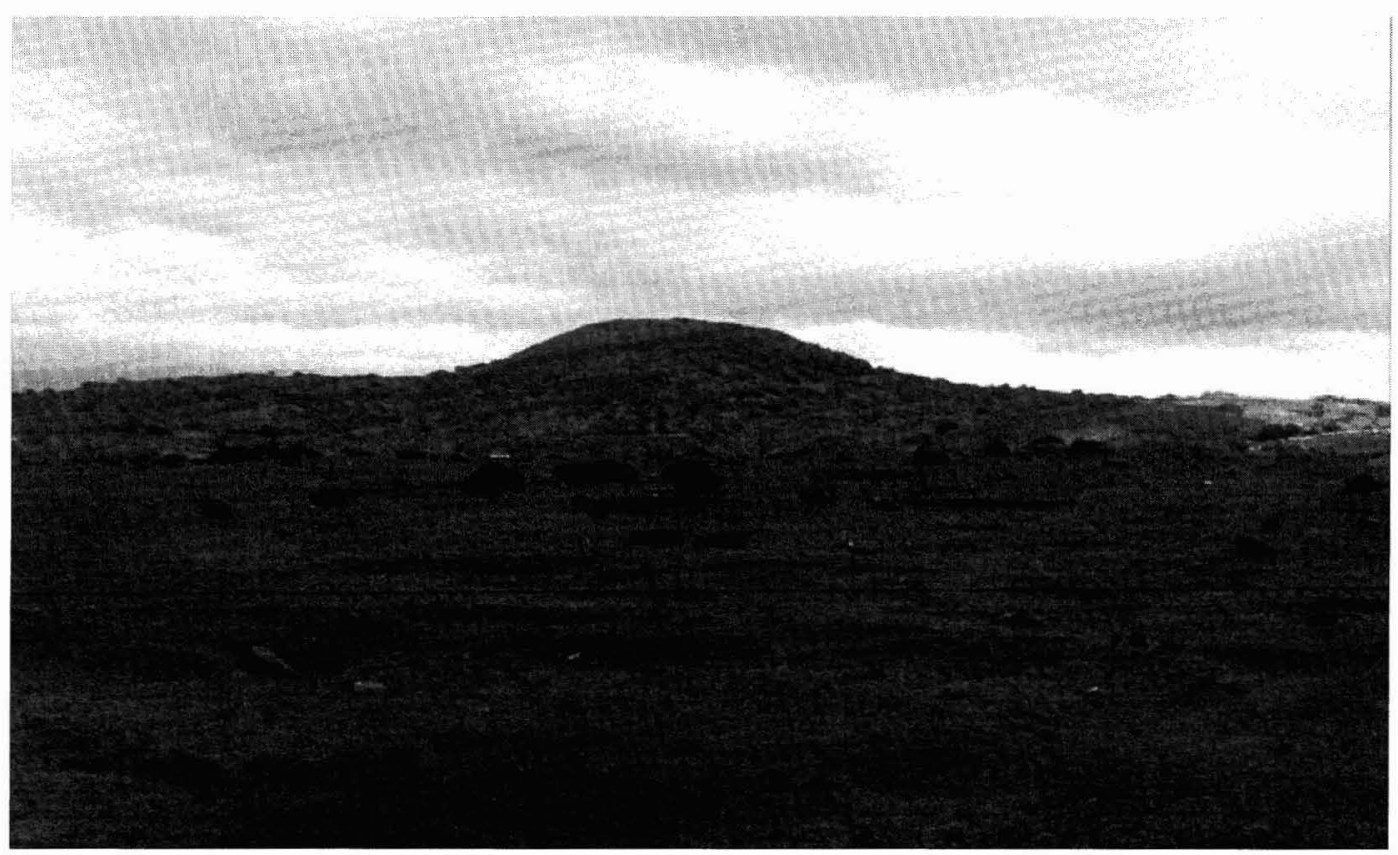

FIGURE 11b. Same location, 1991. The bare, windswept surface is still bare. The white outline of a former military target is visible on the extreme right of the image. Remnants of military ordnance are present in the lower left of the image and on the near horizon beyond the leftmost of the three large boulders in the foreground. 


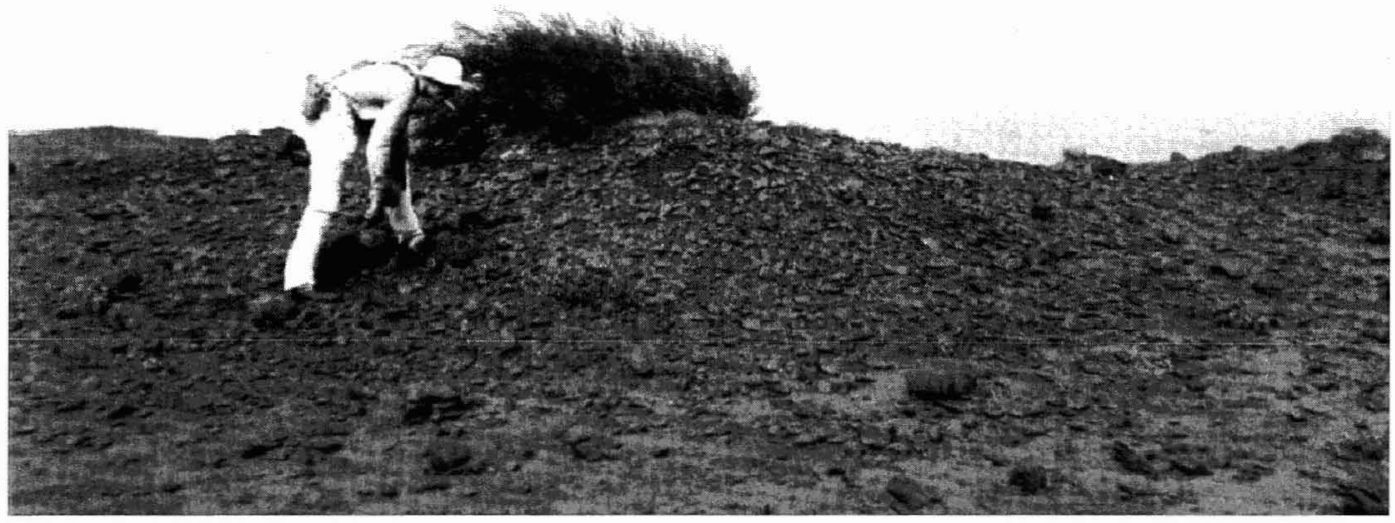

Figure 12a. "Dr. Gordon T. Bowles picking up adze fragments from the quarry on the summit of Puu Moiwi," E. H. Bryan, 1939, Bishop Museum negative no. 19828.

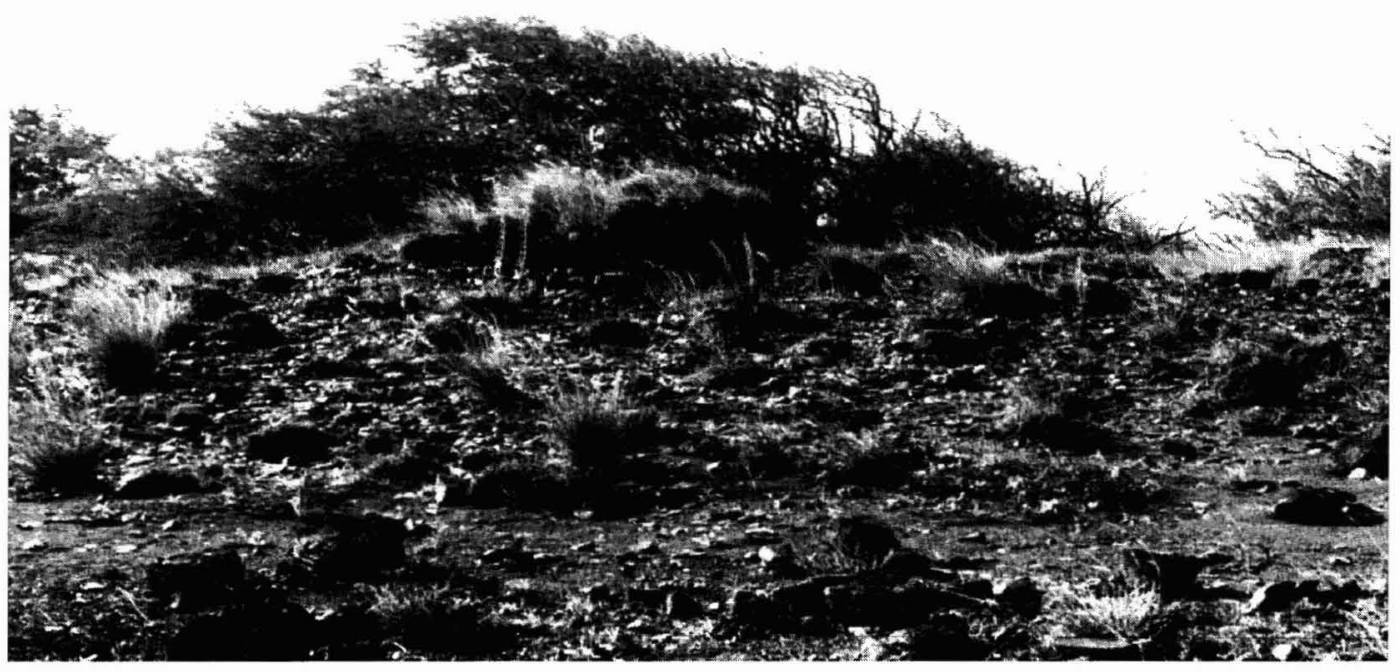

Figure 12b. Same location, 1993. There has been considerable deflation on the right side of the mound, presumably the result of wind erosion as indicated by the pedestalled appearance of the mound. 


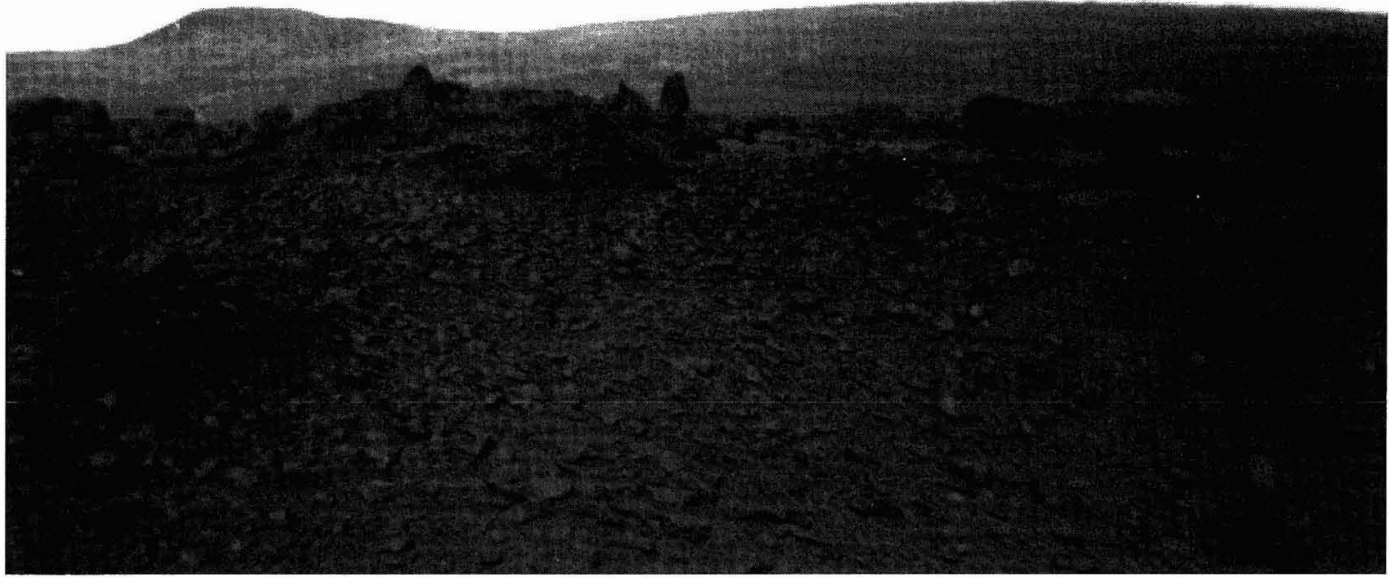

Figure 13a. "Location northeast of Puu Moiwi, scattered with fragments of fine grained basalt, many adze-shaped. In distance, Moaula peak and (right) crater of Lua Makika," E. H. Bryan, 1931, Bishop Museum negative no. 16602.

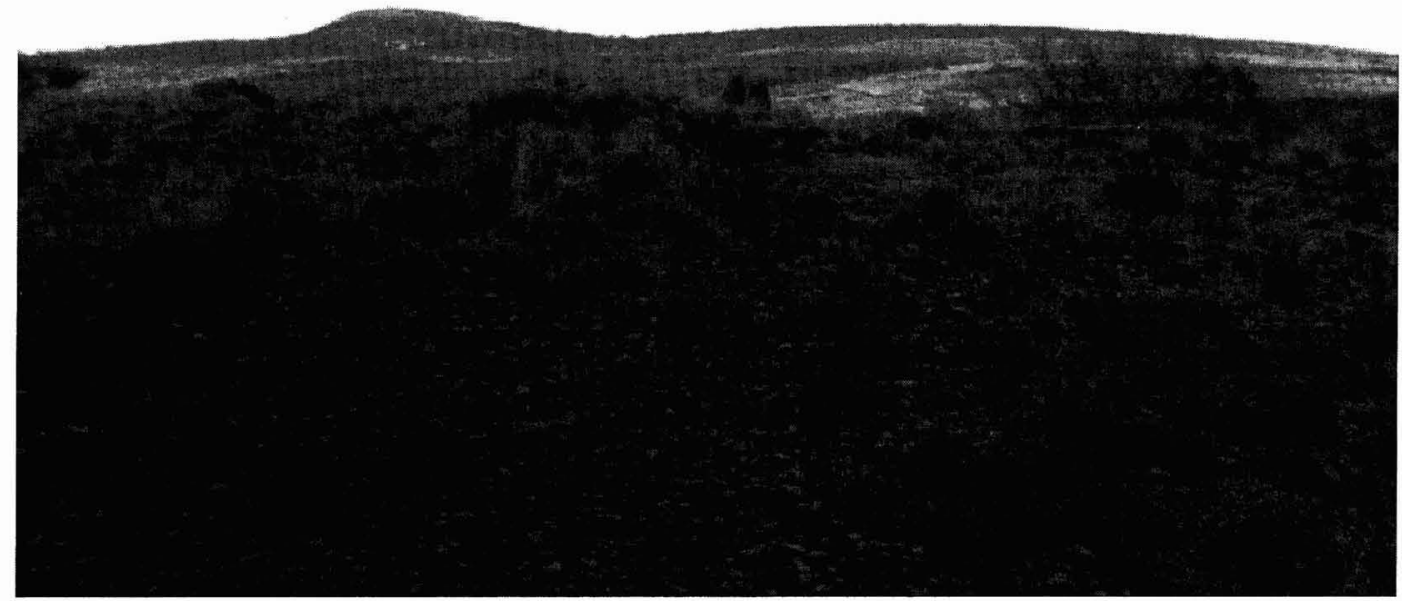

FIGURE 13b. Same location, 1993. Note the increase in vegetation. Note also that one of the two large stones on the near horizon at the center of the 1931 photograph has been positioned upright at some point during the intervening years. 


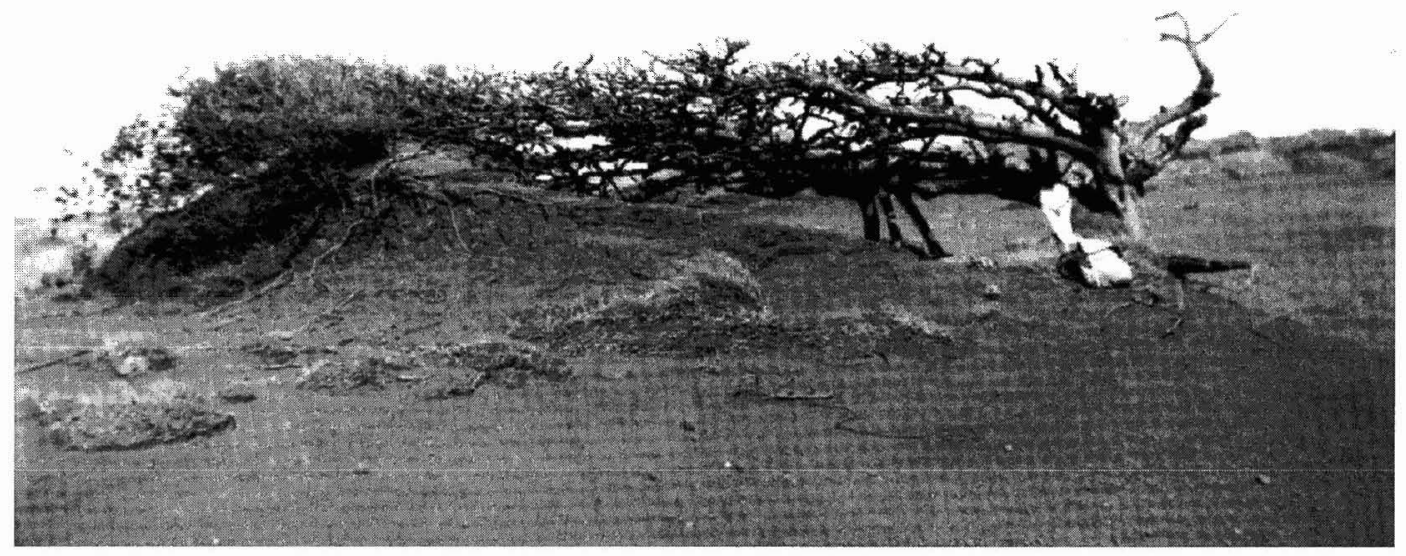

FIGURE 14a. "A wind-blown wiliwili tree on the southwest slope of Lua Makika, in the lee of which the old soil remains as a mound, now surmounted by a lone lantana bush. Eleven-inch [28 cm] ring of insect net for scale," E. H. Bryan, 1939, Bishop Museum negative no. 19826.

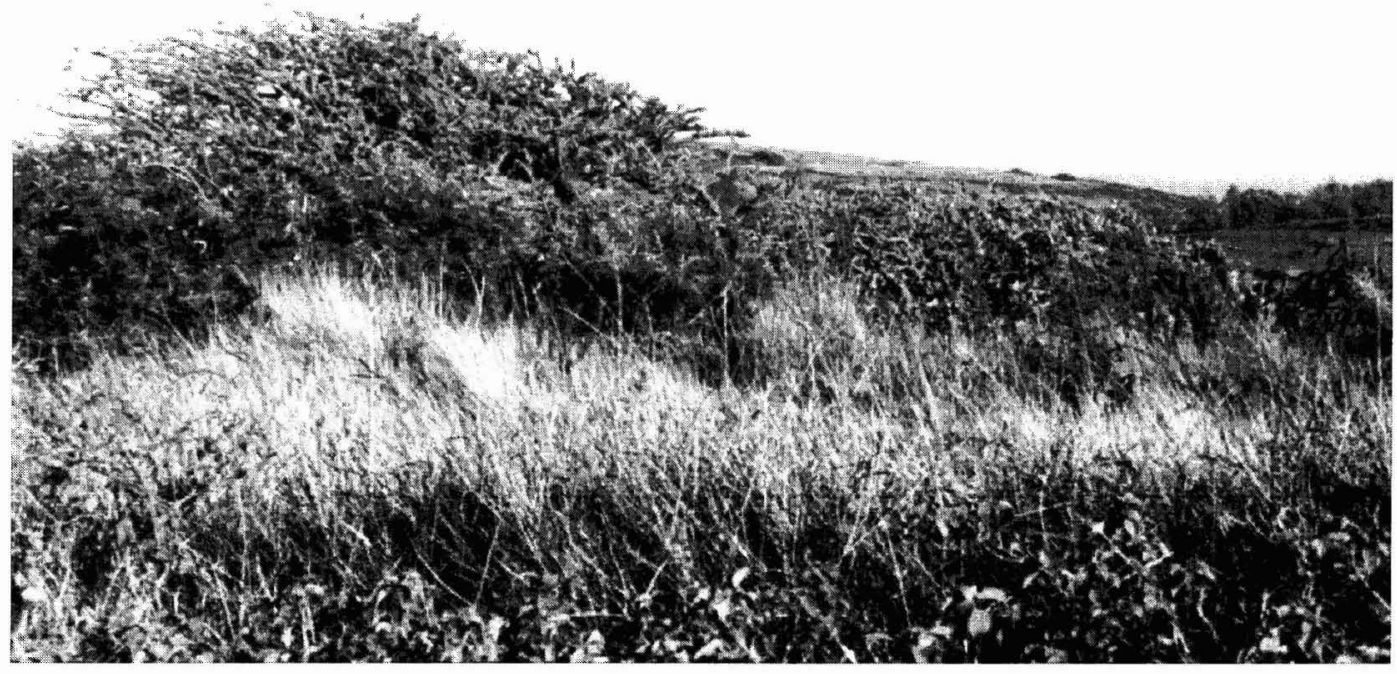

Figure 14b. Same location, 1993. The mound of soil has grown considerably since 1931, indicating that it is more likely aeolian sediments deposited in the lee of the wiliwili (Erythrina sandwicensis) tree, rather than original soil as surmised by Bryan. The growth of the mound is an indication of substantial wind erosion between 1931 and 1993 . However, because the mound is now almost completely vegetated with lantana and grass, it is likely that the degree of wind erosion has subsided in recent years. A row of tamarisk trees planted by the State Division of Forestry is visible on the horizon on the far right side of the photograph. 


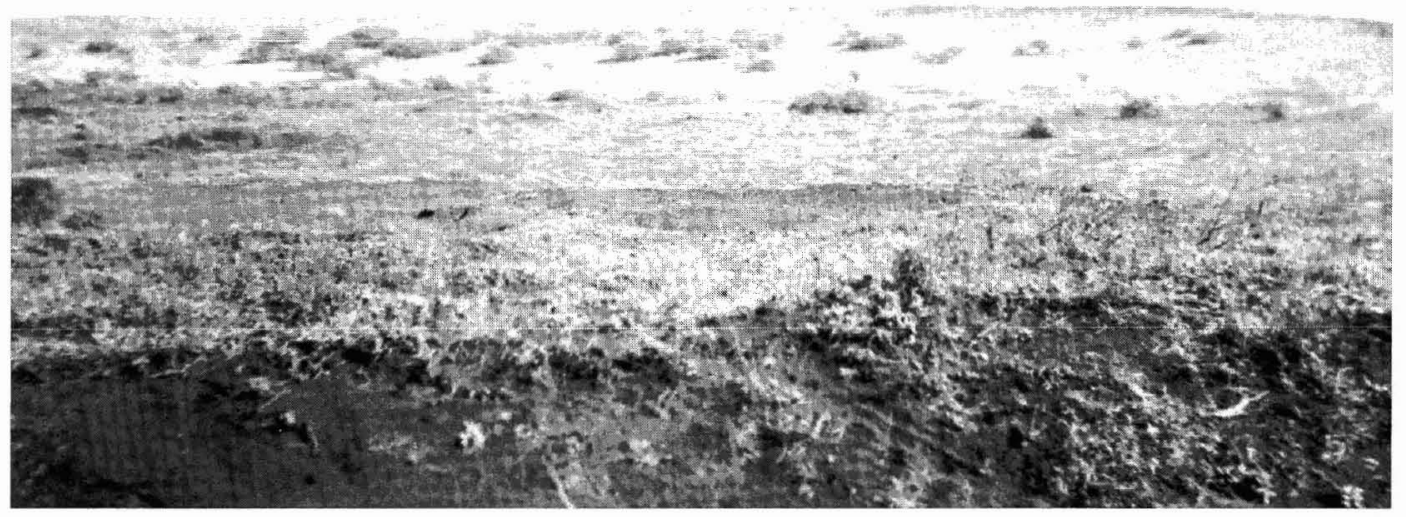

Figure 15a. "Grassy interior of Lua Makika (the translation means 'mosquito hole'), the crater in the highest dome of Kahoolawe, looking north, with the west Maui mountains in the distance," E. H. Bryan, 1939, Bishop Museum negative 19825 .

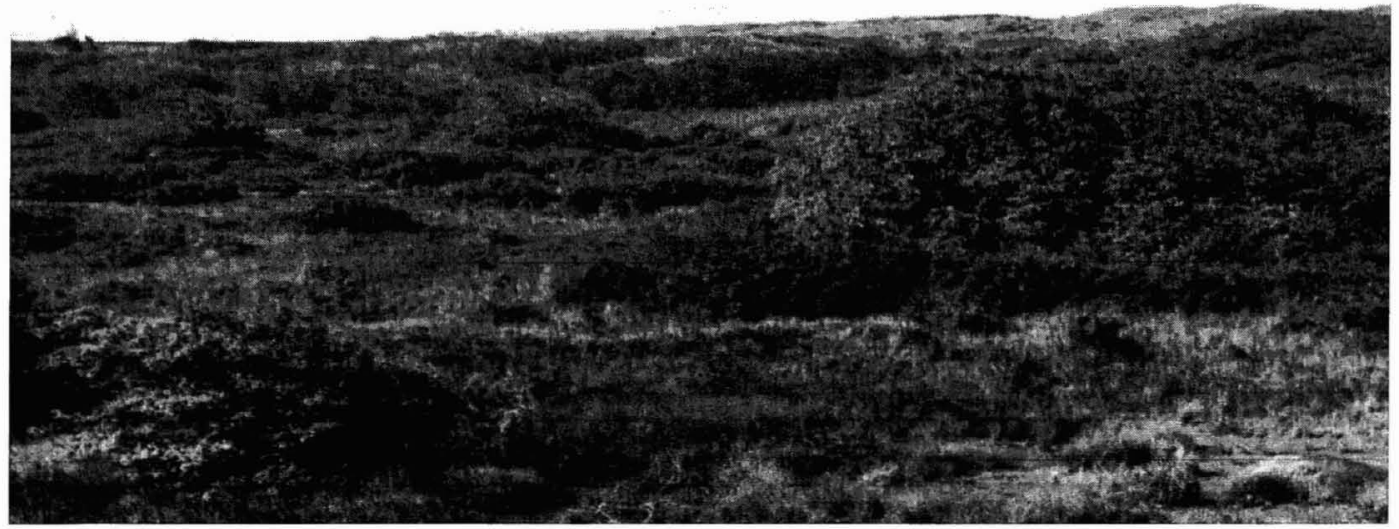

FIGURE 15b. Same location, 1993. The interior of the crater has been invaded by several shrub species. 


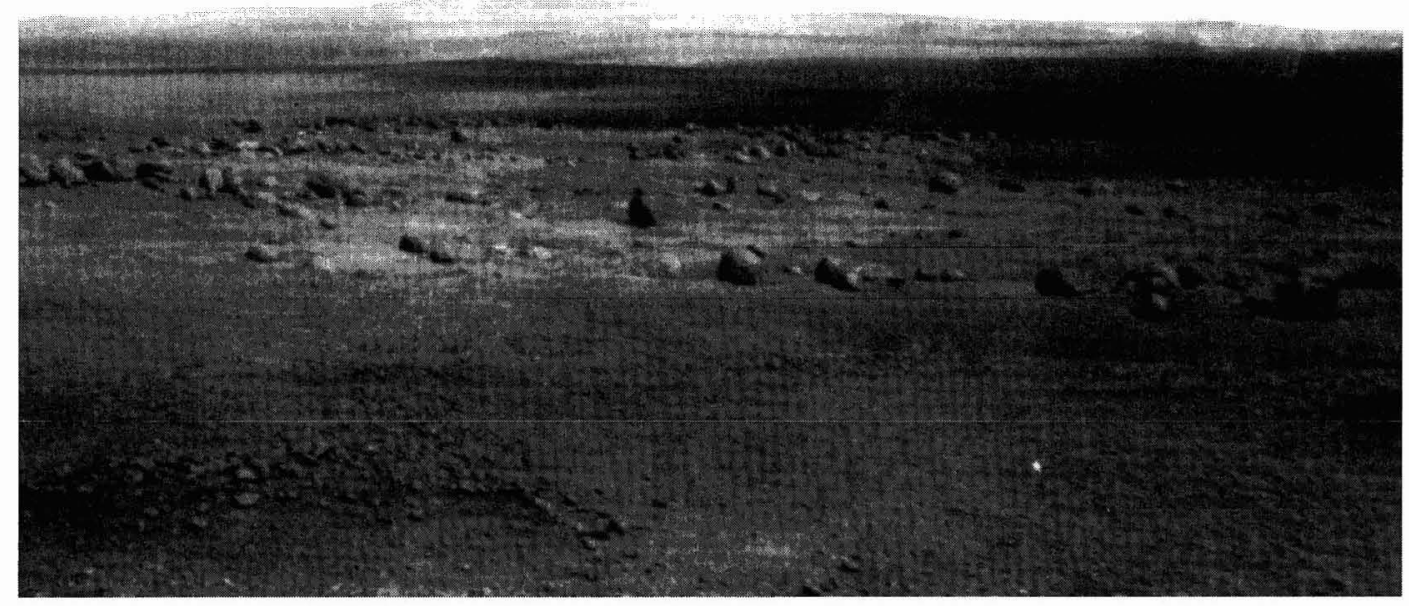

FIgURE 16a. "Interior plateau, bare, wind-swept red soil. Elevation 1038 feet [316 m], looking toward Lua Makika, elevation 1477 feet [450 m]," E. H. Bryan, 1931, Bishop Museum negative no. 16592.

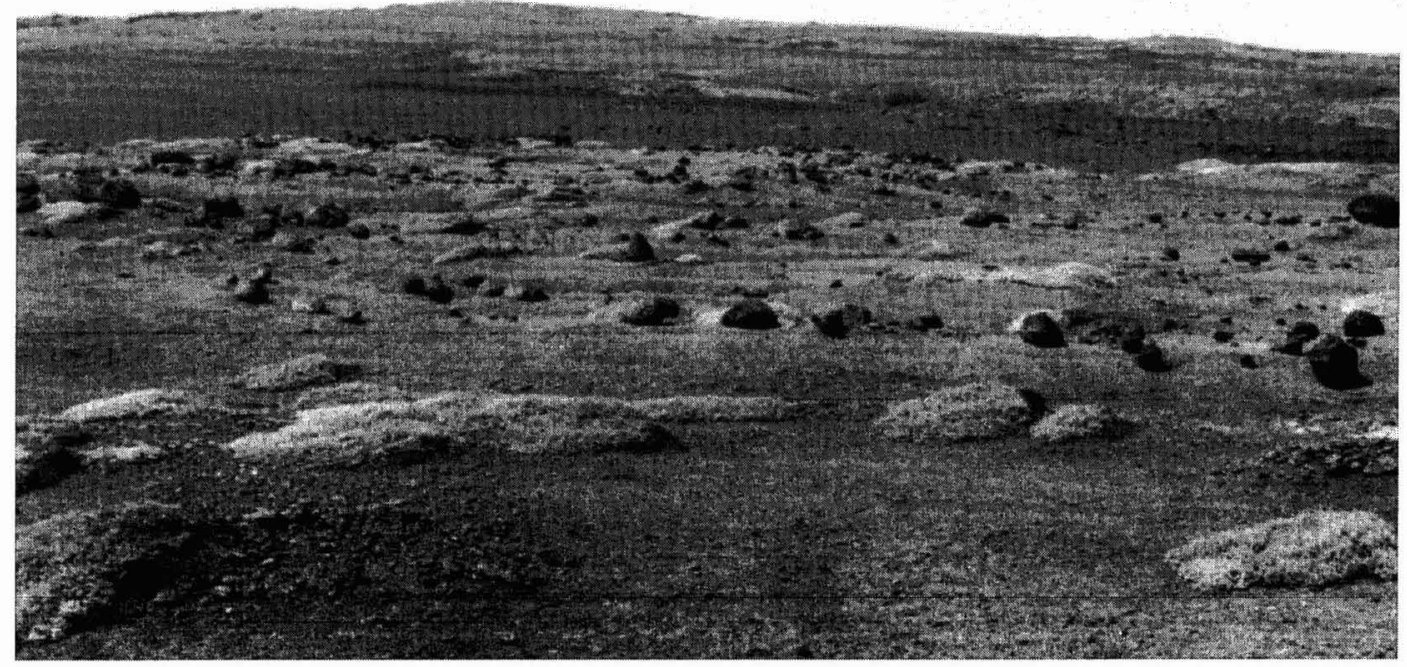

Figure 16b. Same location, 1991. Note the presence of Australian saltbush, the prostrate shrub. 


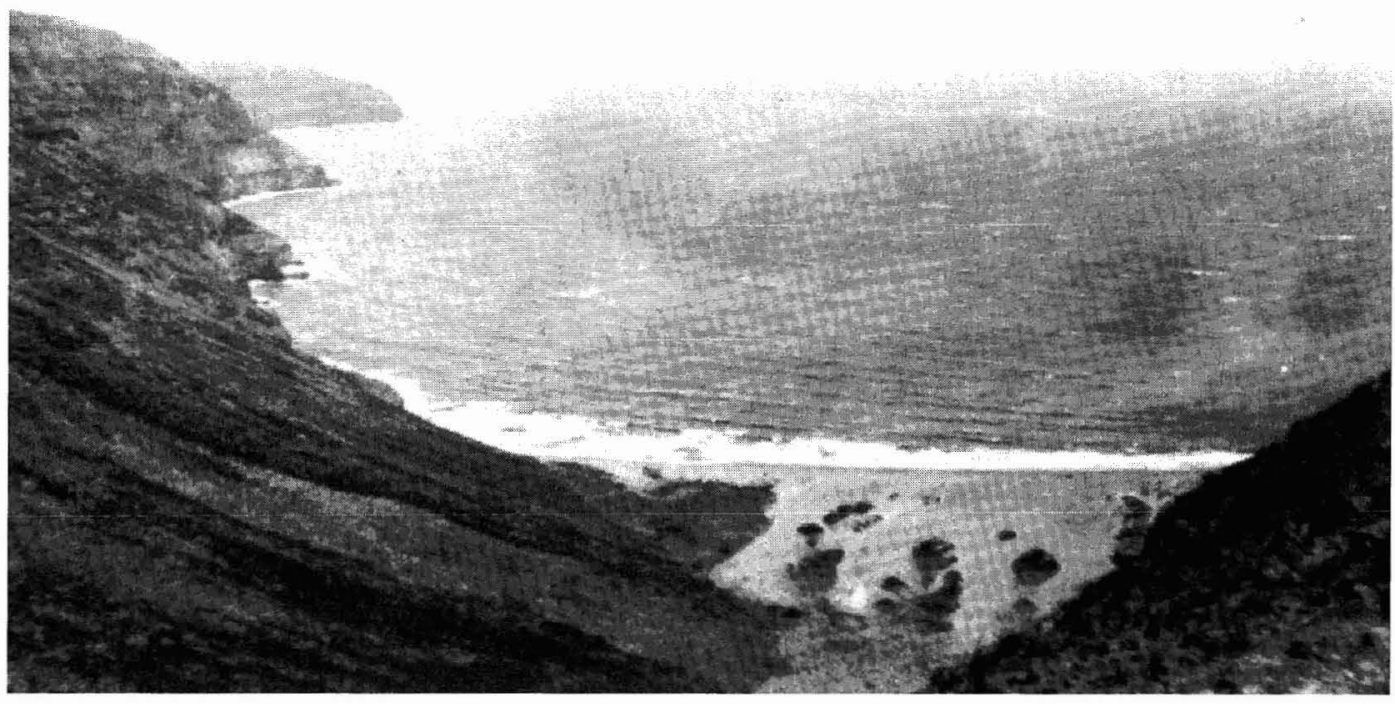

Figure 17a. "Kanapou Bay, looking toward Maui. From elevation of about 700 feet [213 m]," E. H. Bryan, 1931, Bishop Museum negative no. 16582.

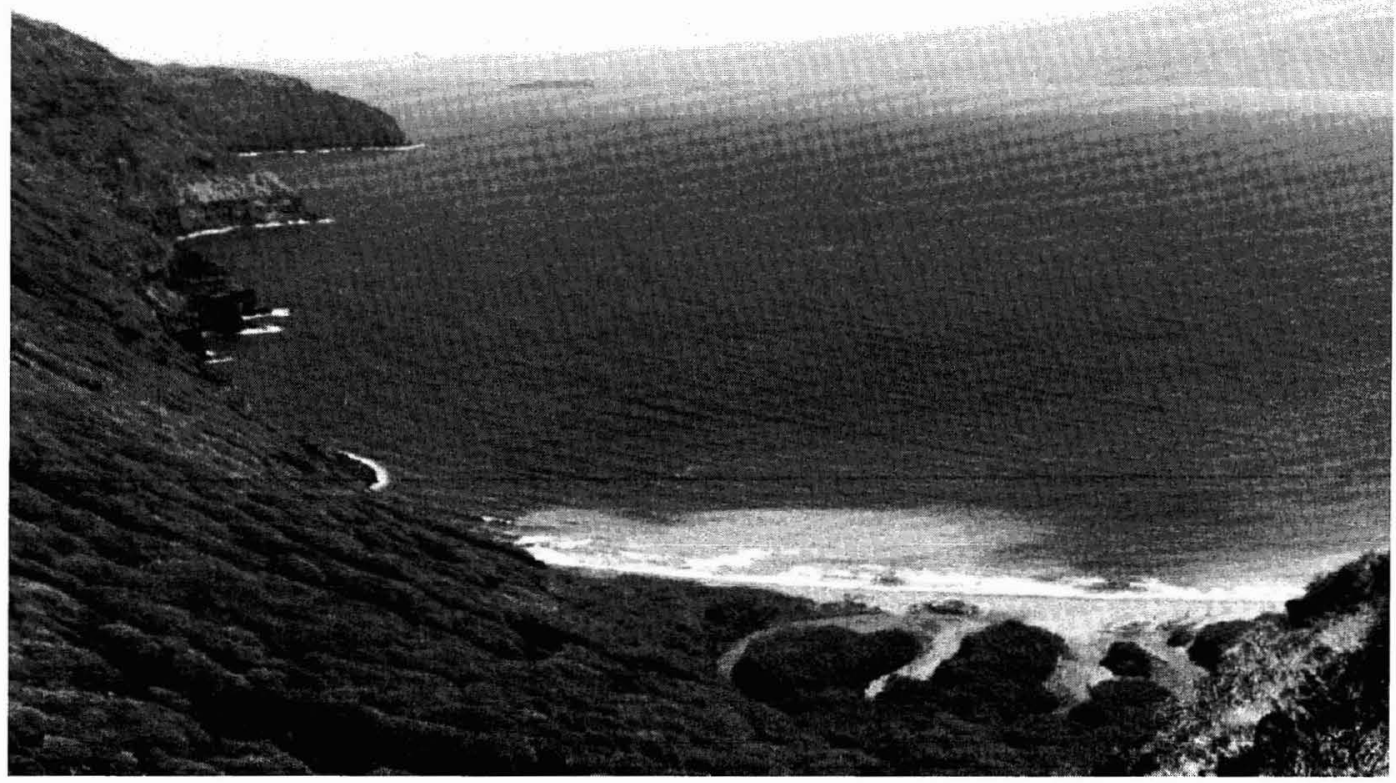

FigUre 17b. Same location, 1991. The west end of Maui is visible in the distance. Molokini atoll is visible between Kaho'olawe and Maui. Note the increase in kiavve on the hillslopes and beach. 


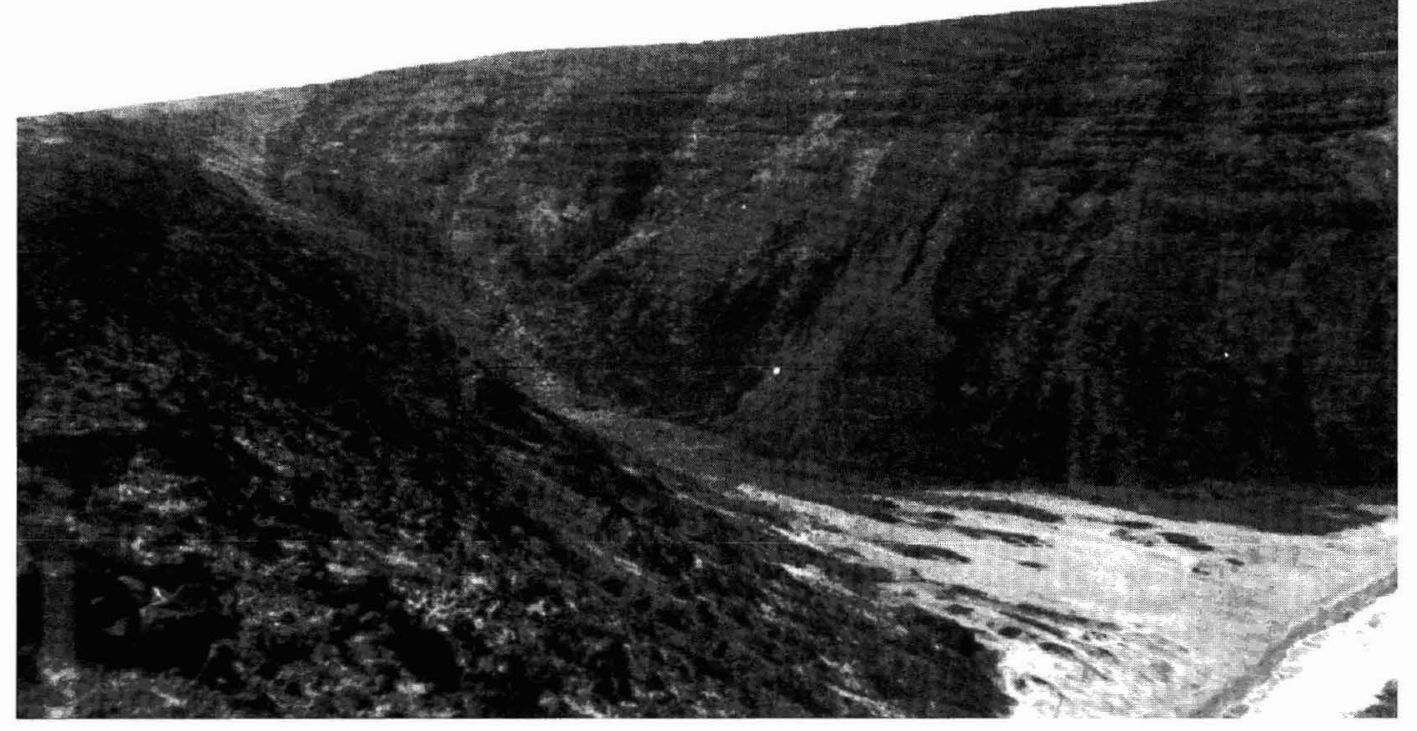

Figure 18a. "Gulch behind Kanapou Bay, from the south cliff, elevation about 600 feet [243 m]," E. H. Bryan, 1931, Bishop Museum negative no. 16583.

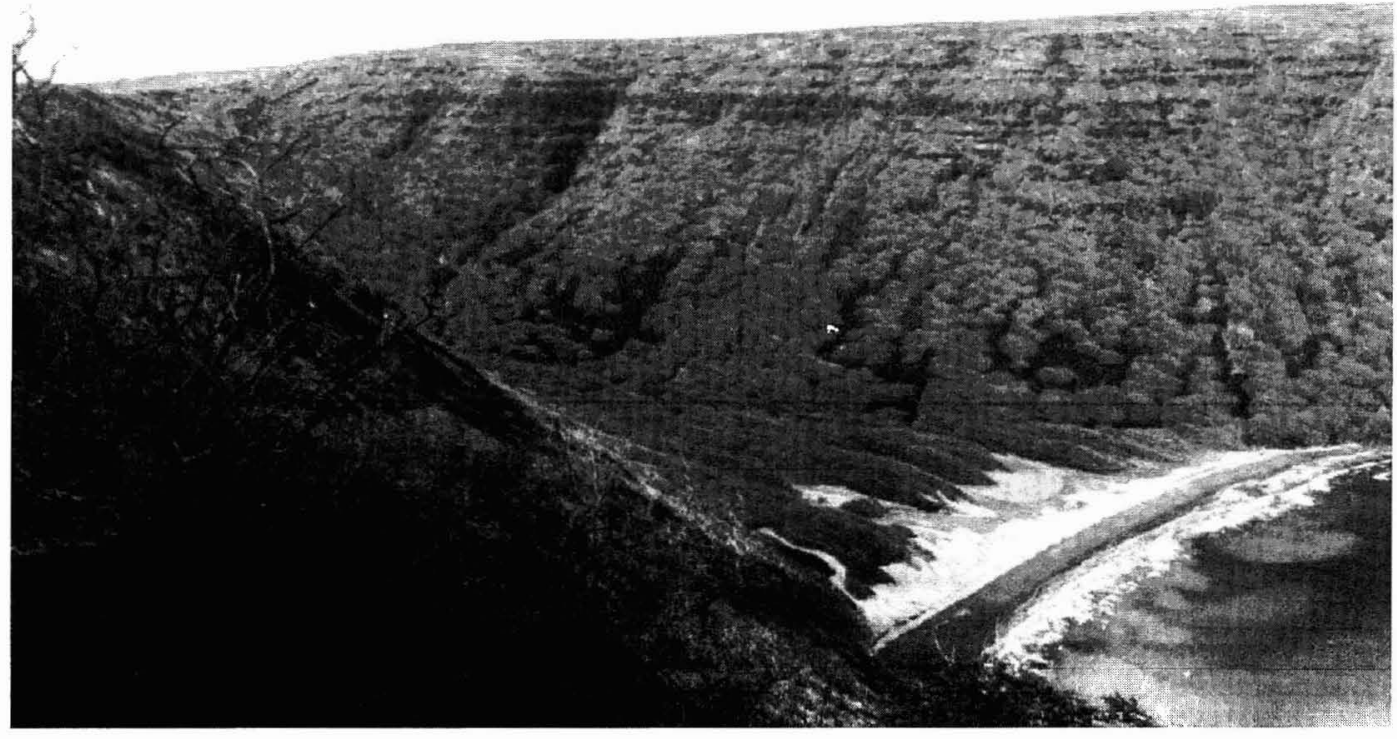

FIGURE 18b. Same location, 1991. Note the increase in kiawe on the hill slopes and beach. 


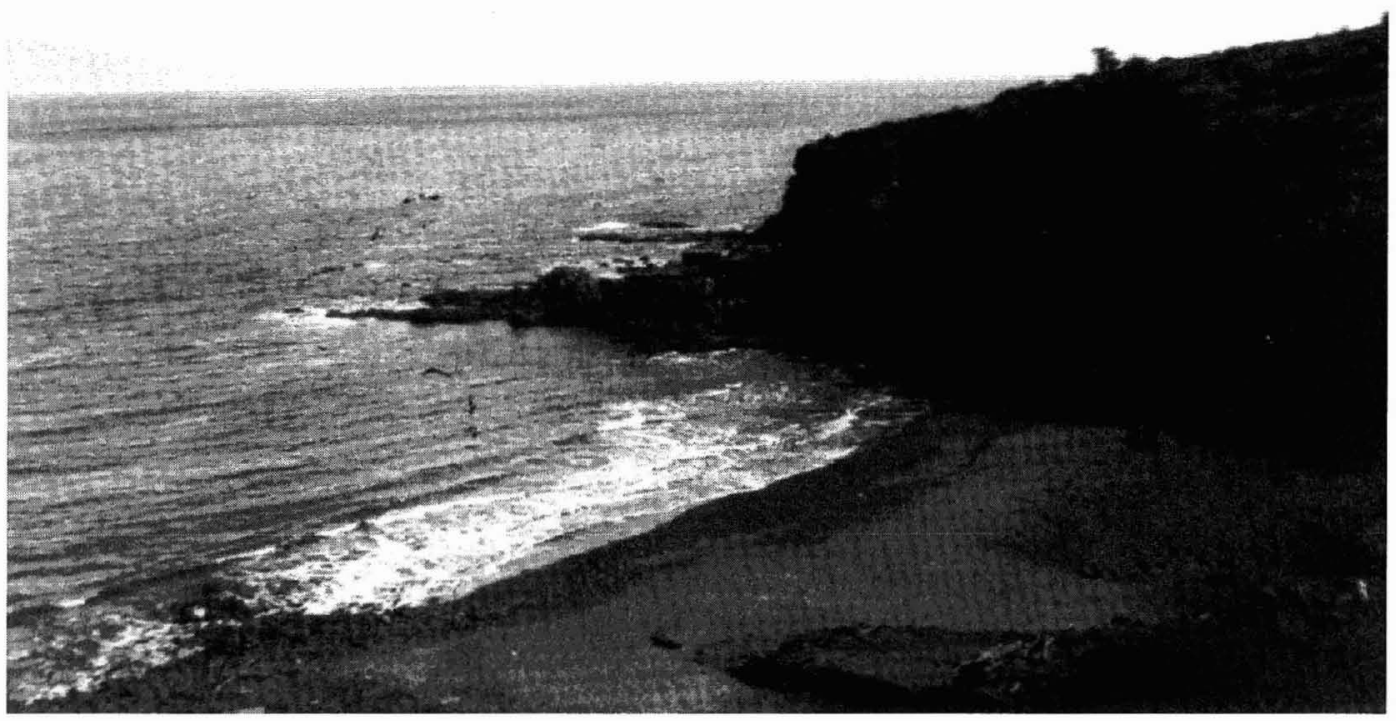

FigUre 19a. "Panorama of Papakanui Bay, looking north-northeast toward West Maui from elevation of about 100 feet [30 m]," E. H. Bryan, 1931, Bishop Museum negative no. 16586.

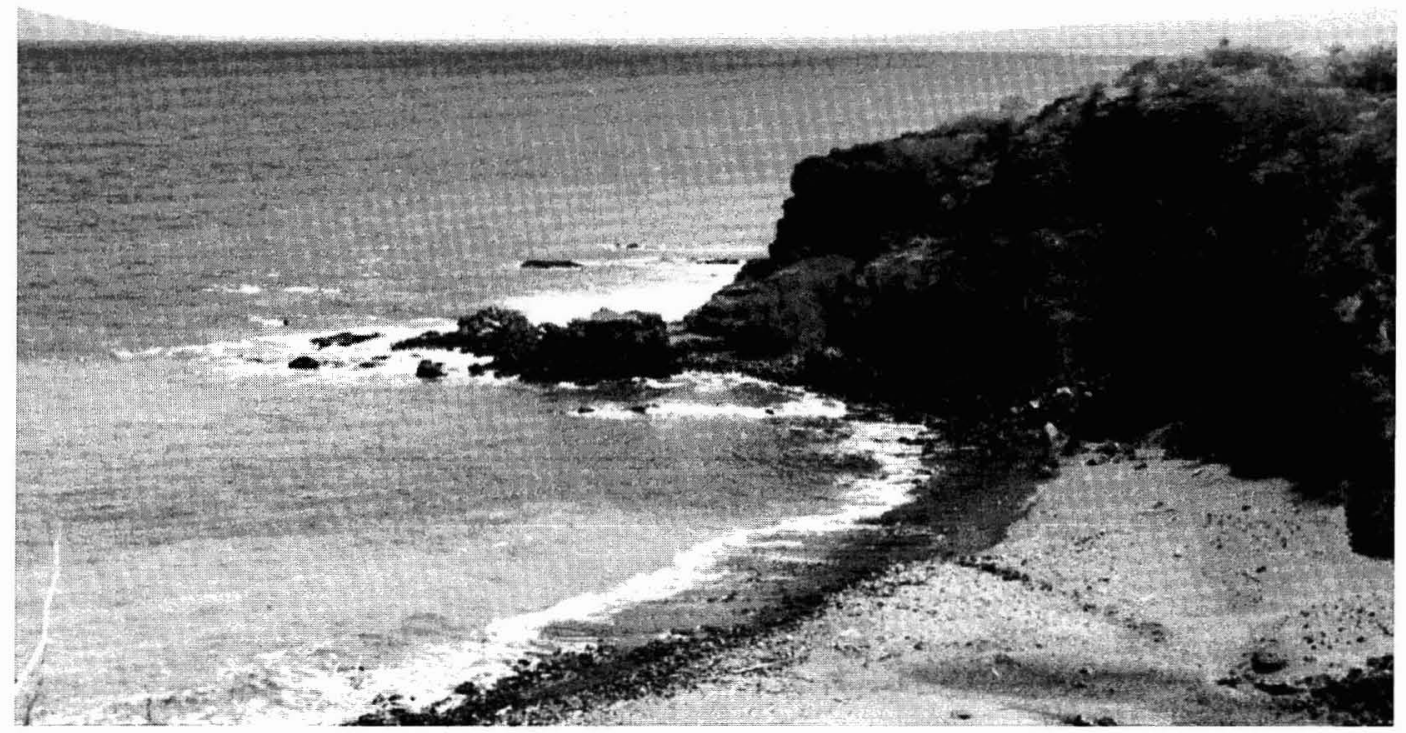

Figure 19b. Same location, 1991. A plume of darker colored alluvial deposits present on the beach in the 1931 photo is also present in 1991, indicating that severe water erosion continues on the island. The east and west ends of Maui are visible on the right and left sides of the horizon, respectively. 


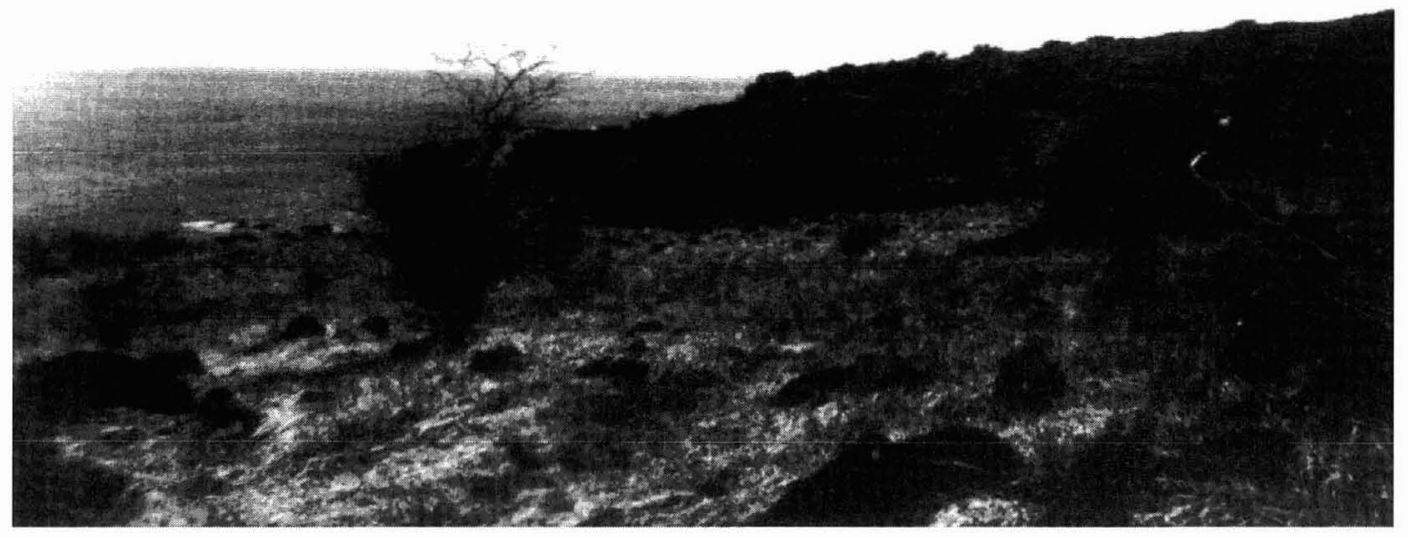

FigUre 20a. "Looking east across Papakaiki Gulch toward Haleakala. Typical growth of algaroba and pili grass," E. H. Bryan, 1931, Bishop Museum negative no. 16587. The location was misidentified by Bryan. The actual location is the outlet of Wa'aiki Gulch.

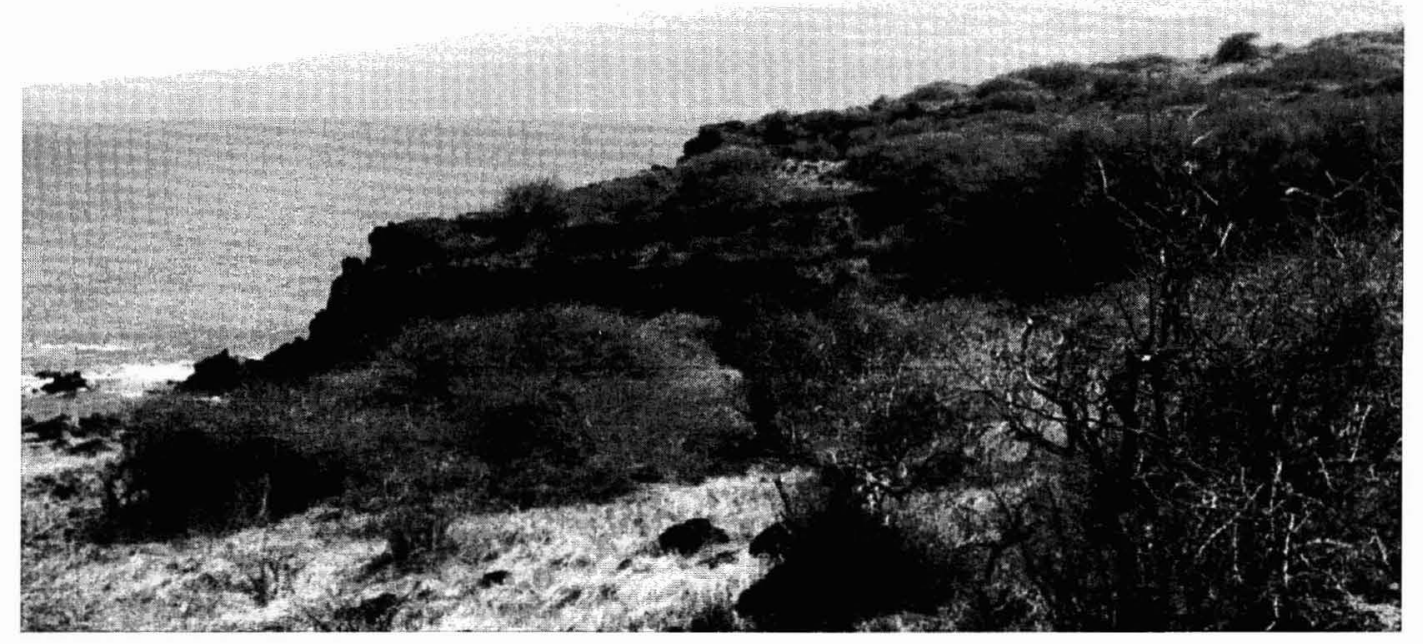

FIgURE 20b. Same location, 1991. The actual view is completely obscured by a dense growth of kiawe. Hence, this photo was taken from approximately $2 \mathrm{~m}$ north of the original. Haleakalā, forming the east end of Maui, is visible in both photographs. 


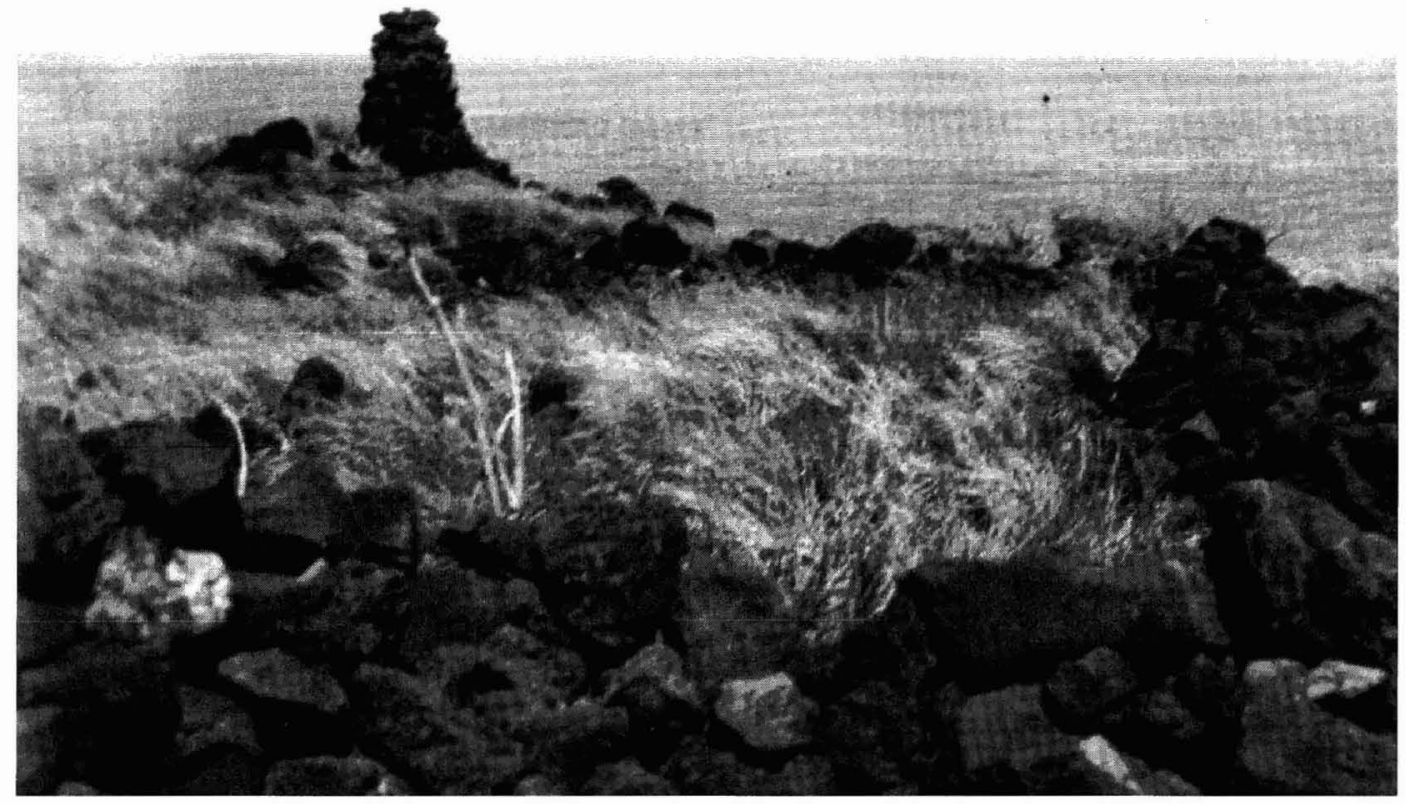

FIGURE 21a. "House site at Lae O Kuikui, the northern point, with the Crack triangulation station indicated in the back ground by a pile of stones,” J. G. McAllister, 1931, Bishop Museum negative no. 15483.

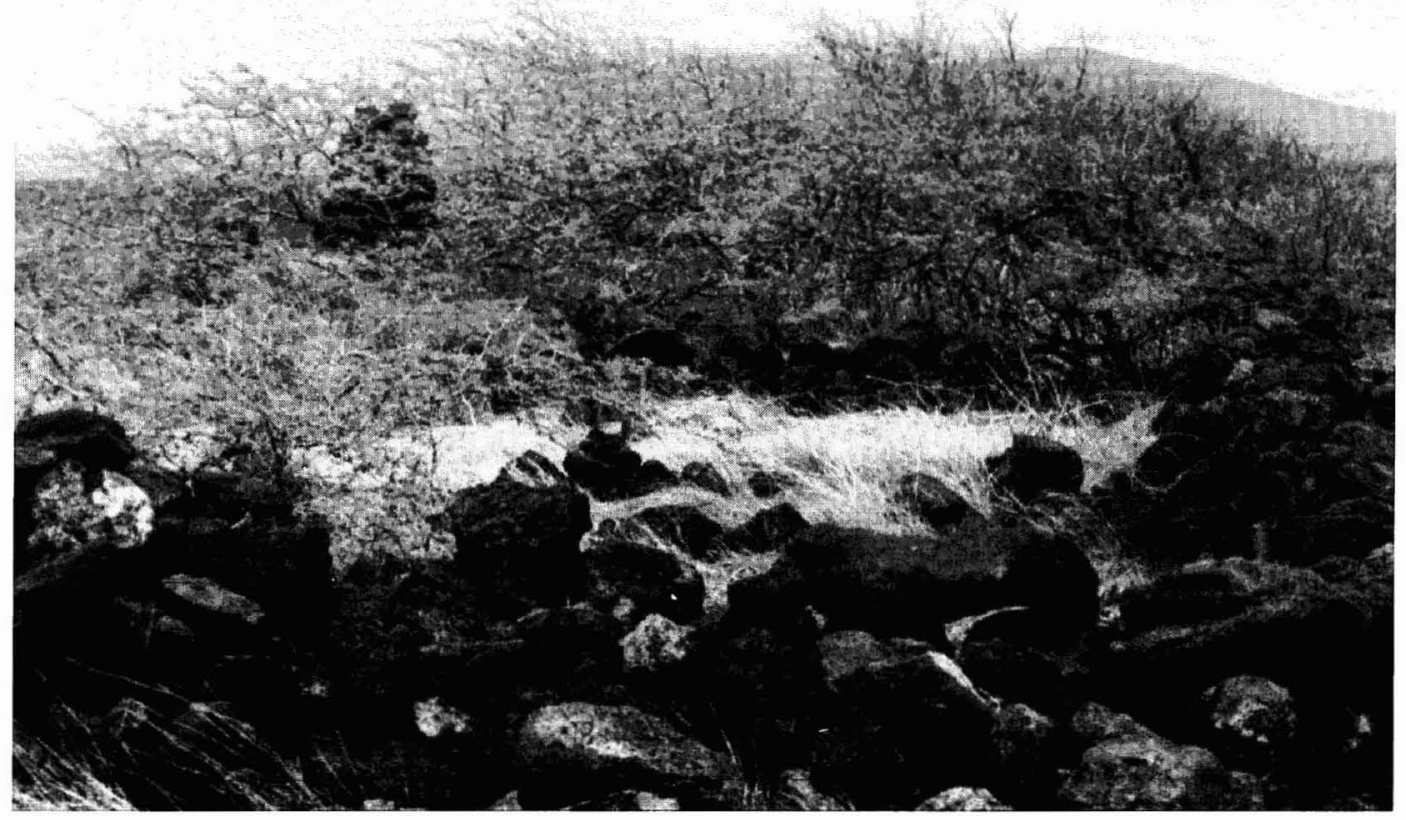

FIGURE 21b. Same location, 1993. The pile of stones is still present, although mostly obscured by kiawe. The western end of Maui, seen unobscured in the 1931 photo, is scarcely visible here to the right of the kiawe. 




FIGURe 22a. "Lae O Kuikui, looking towards Lanai. McAllister at a house platform. Luxuriant growth of pili grass in foreground," E. H. Bryan, 1931, Bishop Museum negative no. 16587. This is a distant view of the same site as Figure 21.

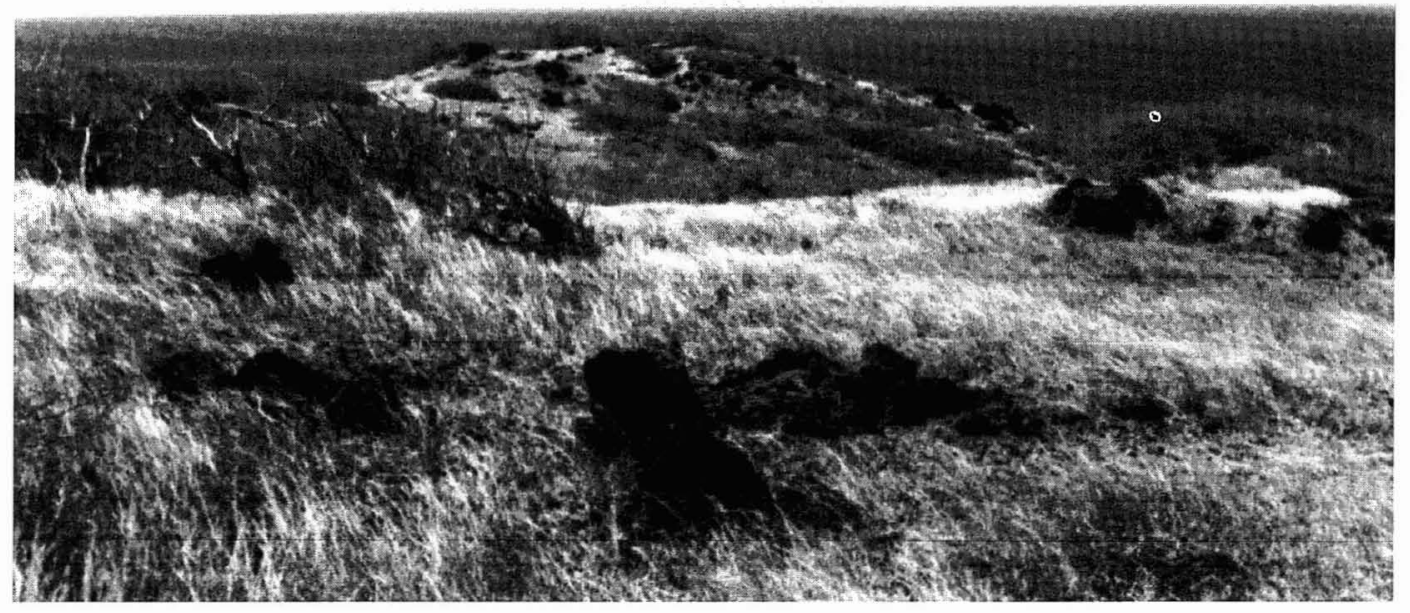

Figure 22b. Same location, 1993. Note the increase of kiawe since 1931. Lāna'i is visible in both photographs. 


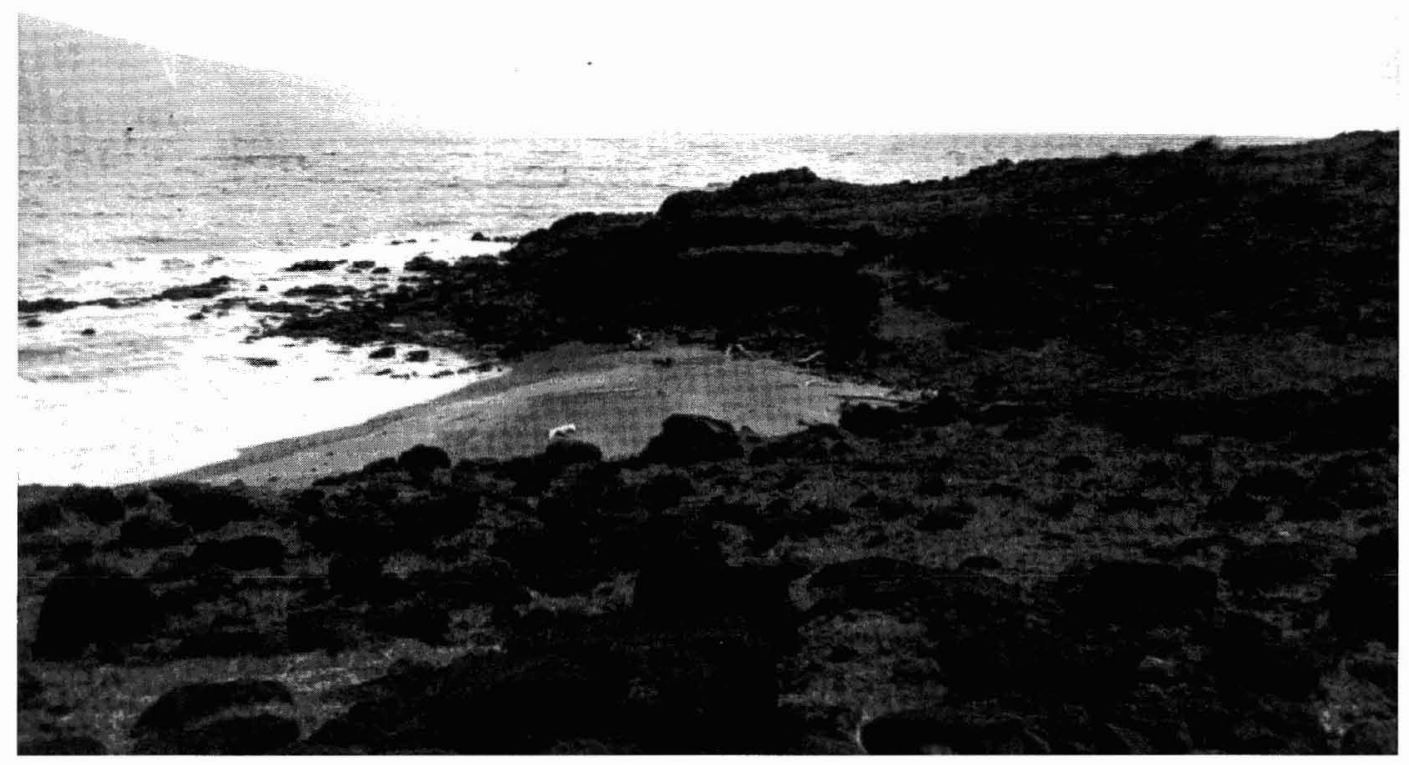

FIGURE 23a. "Small enclosure on the south side of a small gulch just north of Hakioawa," J. G. McAllister, 1931, Bishop Museum negative no. 15485 .

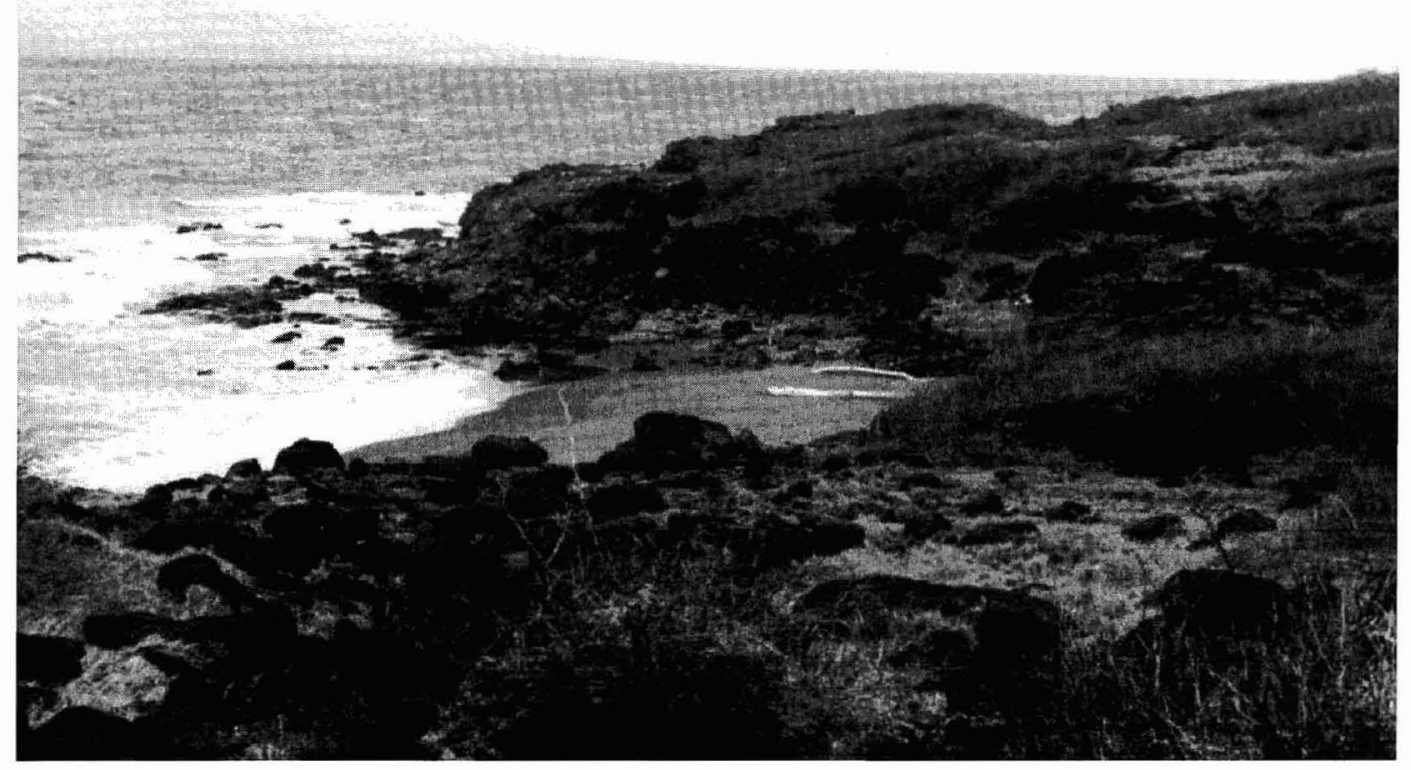

FigURE 23b. Same location, 1993. Note the increase in grass and shrubs. The eastern end of Maui is visible in both photographs. 


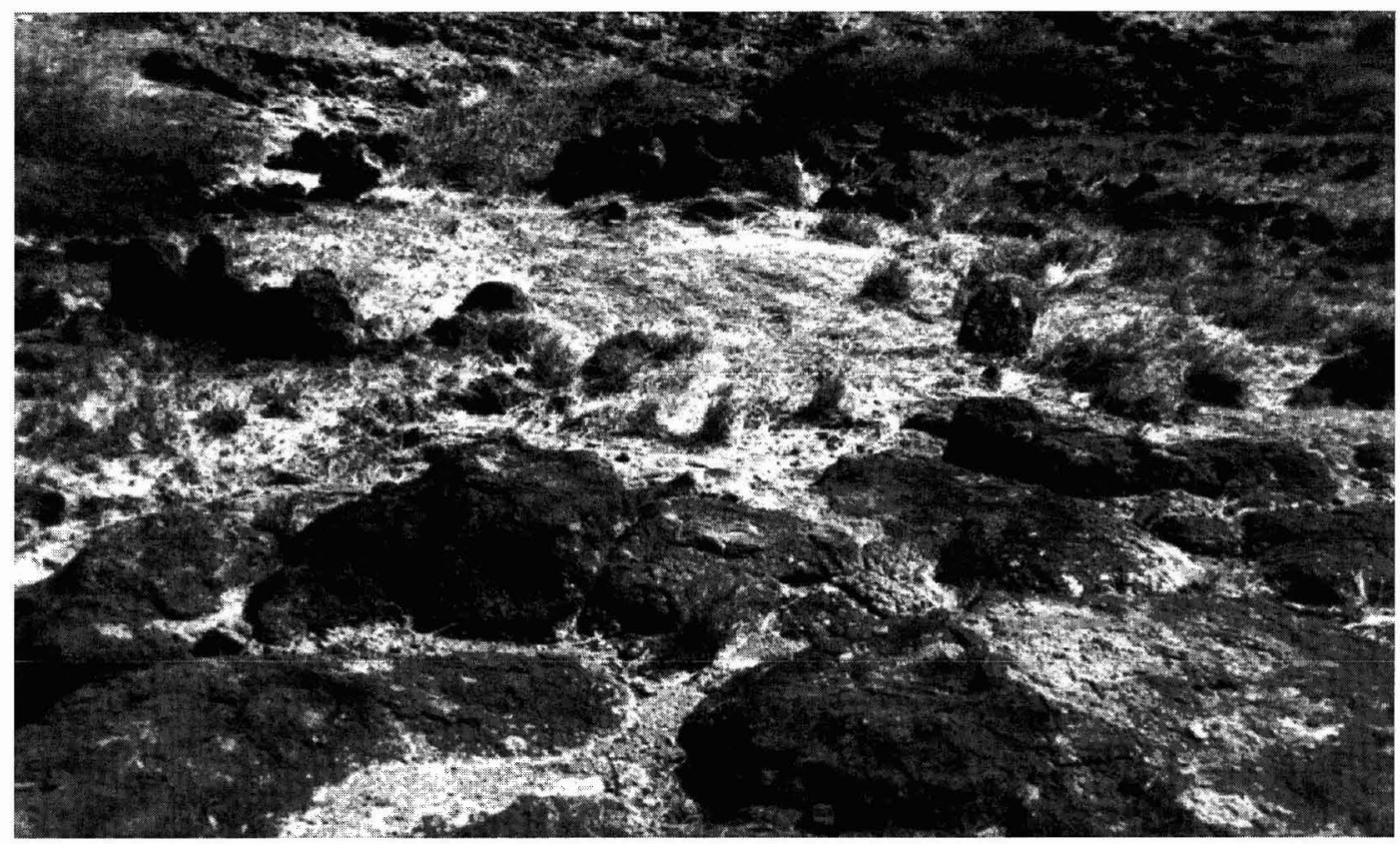

Figure 24a. "House foundation at the small gulch north of Hakioawa," J. G. McAllister, 1931, Bishop Museum negative no. 15484. The house foundation is the pile of stones near the top center of the photograph.

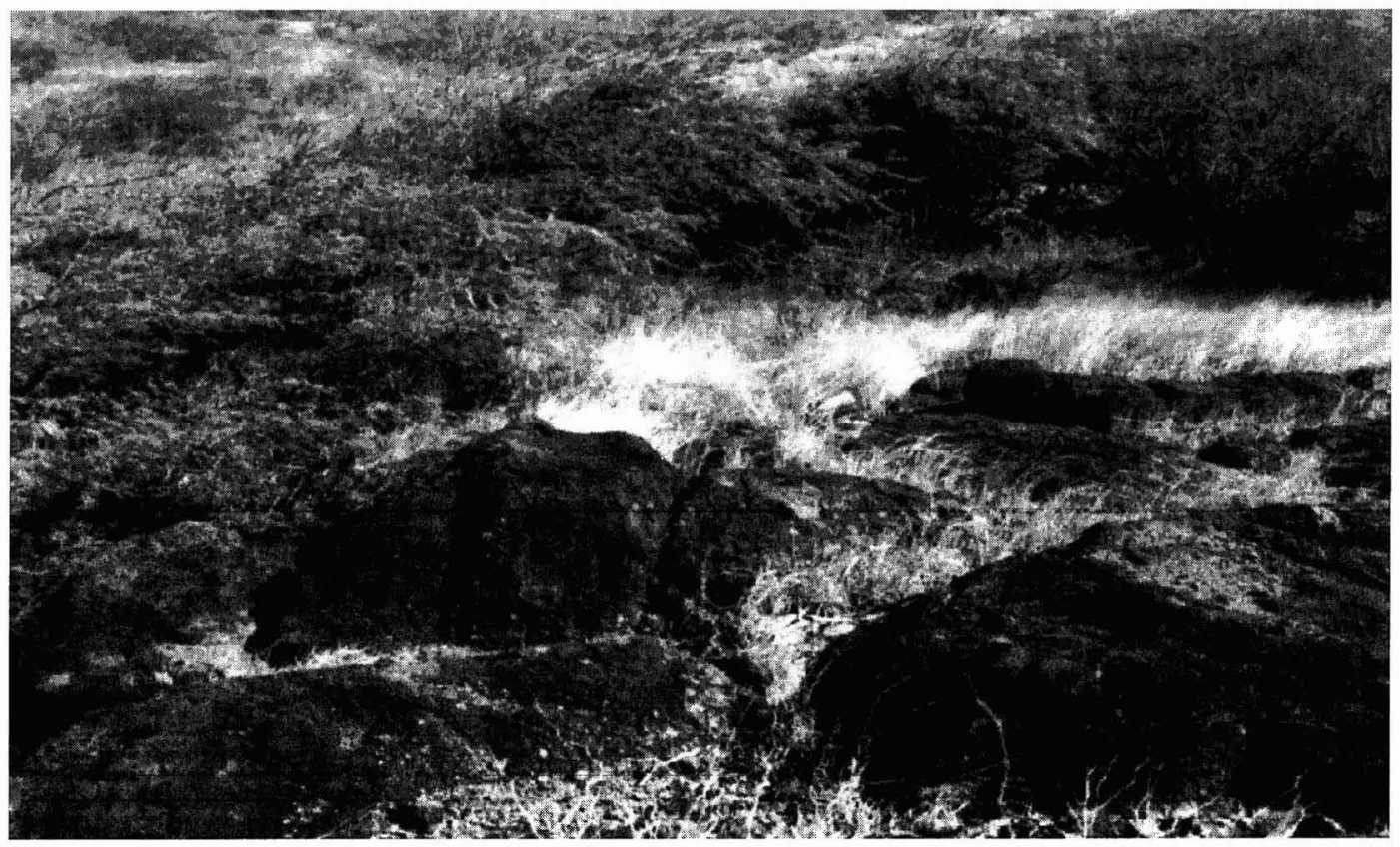

Figure 24b. Same location, 1993. The foundation is almost completely obscured by a dense growth of kiawe. 


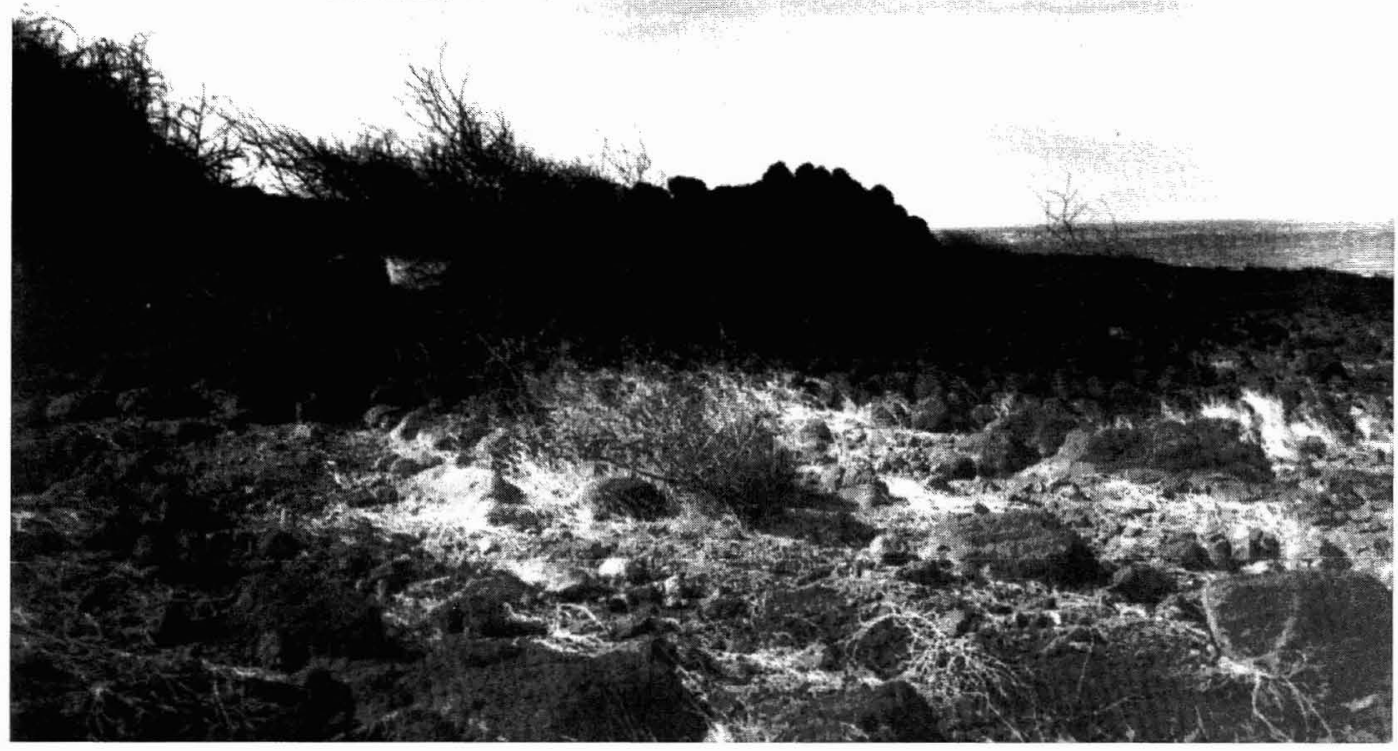

FigUre 25a. "Large pile of stones 6 feet $[1.8 \mathrm{~m}]$ high and 26 by 30 feet $[8$ by $9 \mathrm{~m}]$ in area, on the north slope of Hakioawa Gulch," J. G. McAllister, 1931, Bishop Museum negative no. 15486.

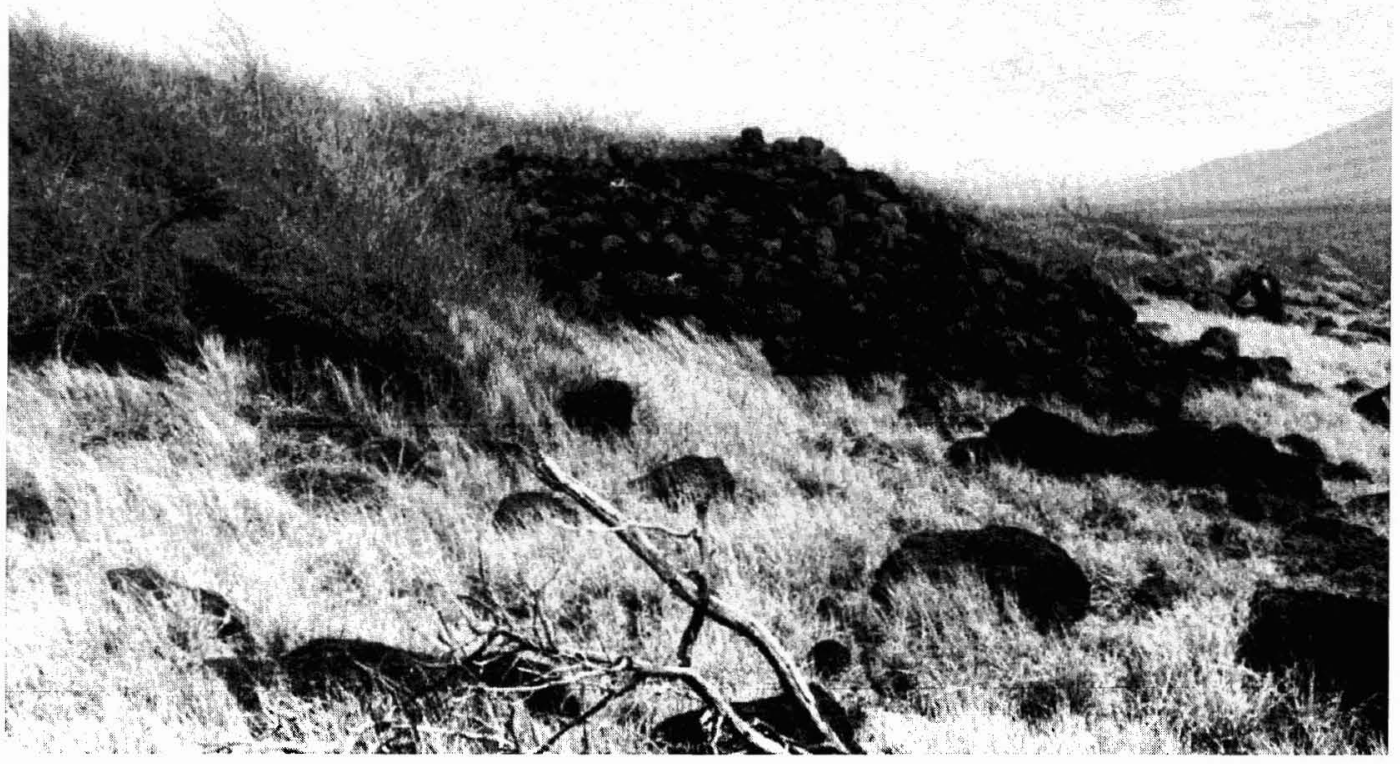

FIgURE 25b. Same location, 1993. Note the increase in grass. The west end of Maui is visible on the right horizon. 


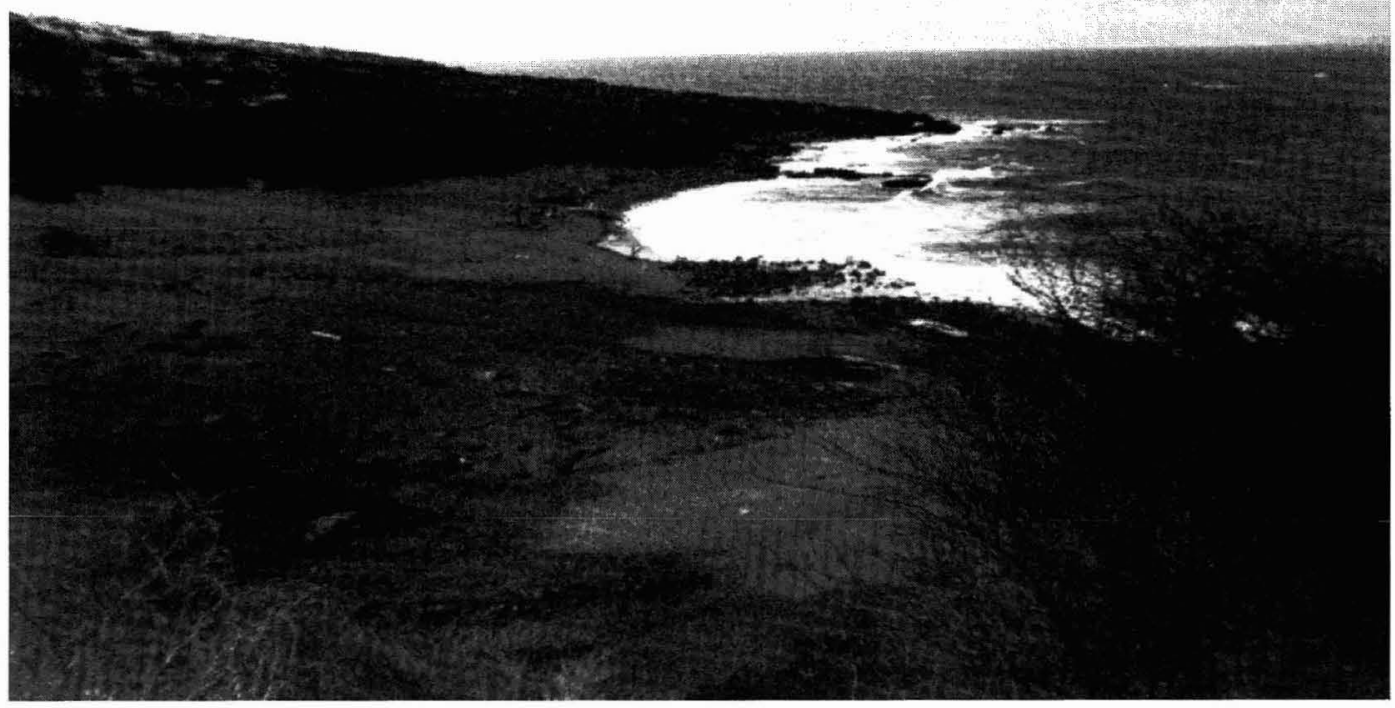

Figure 26a. "Hakioawa beach," E. H. Bryan, 1931, Bishop Museum negative no. 16589.

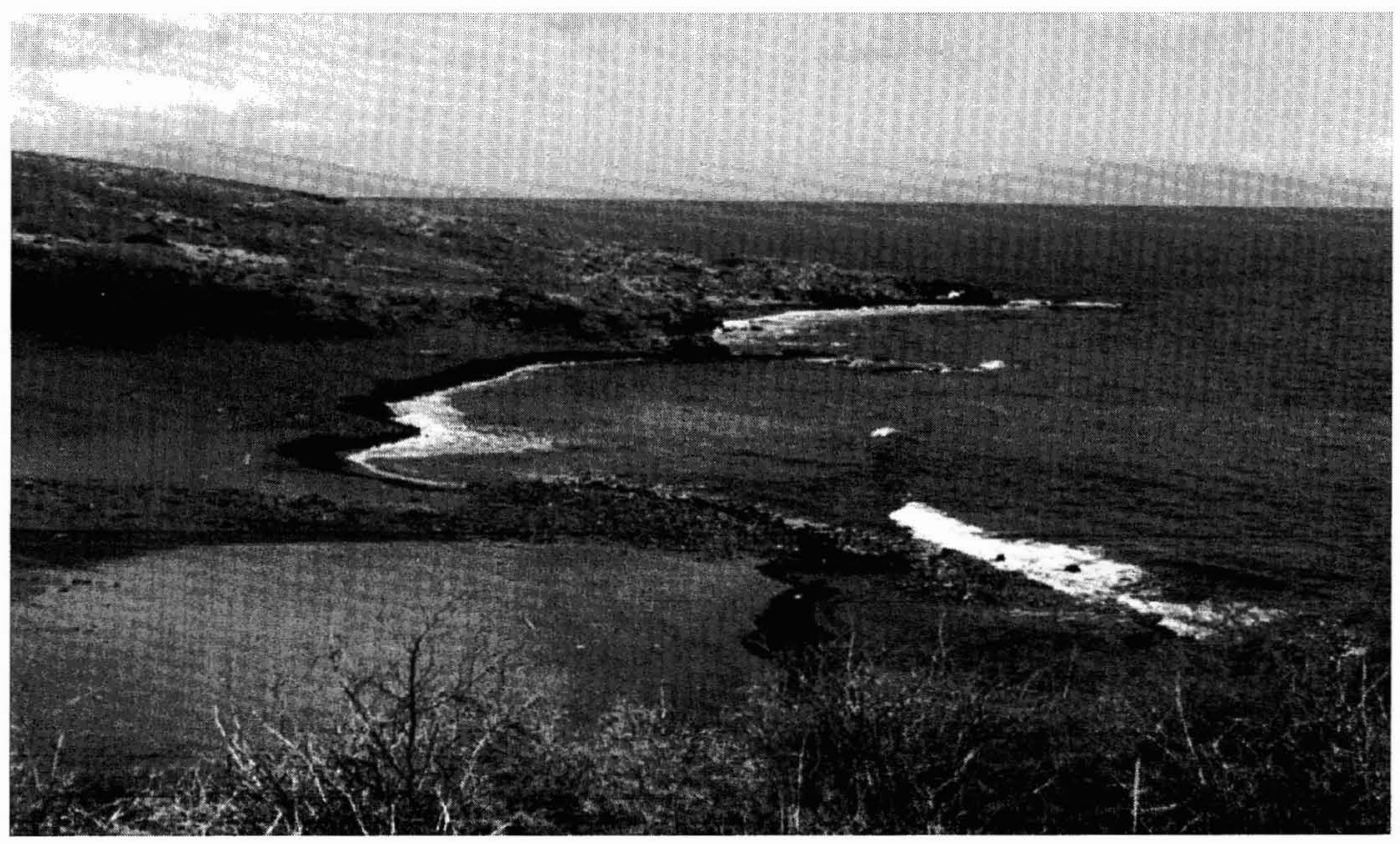

FIGURE 26b. Same location, 1991. The dark-colored plume of alluvial sediments in the center of the beach is present in 1931 and 1991, indicating continued severe water erosion in the uplands. 


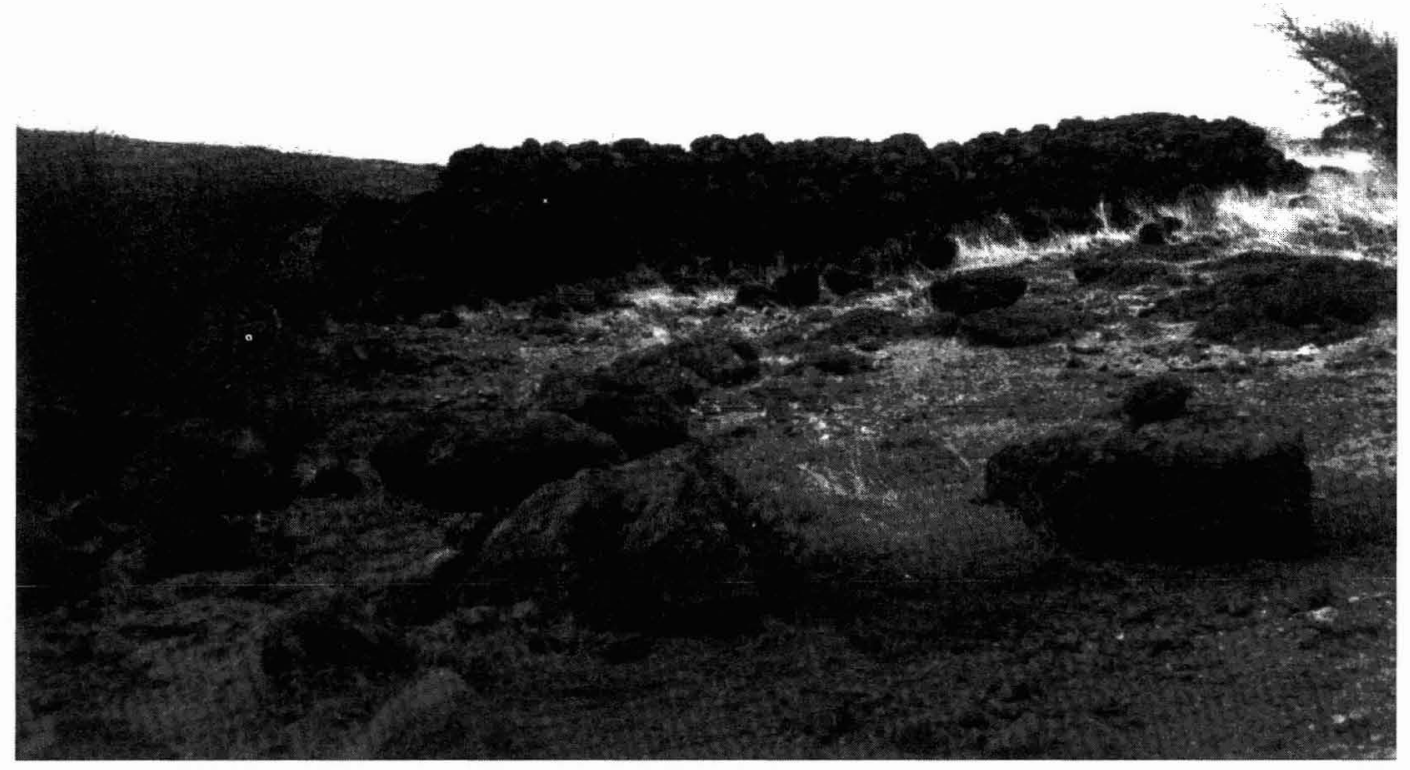

Figure 27a. "East wall of small enclosure, said by Stokes to be a heiau at, Hakioawa gulch," J. G. McAllister, 1931, Bishop Museum negative no. 15487.

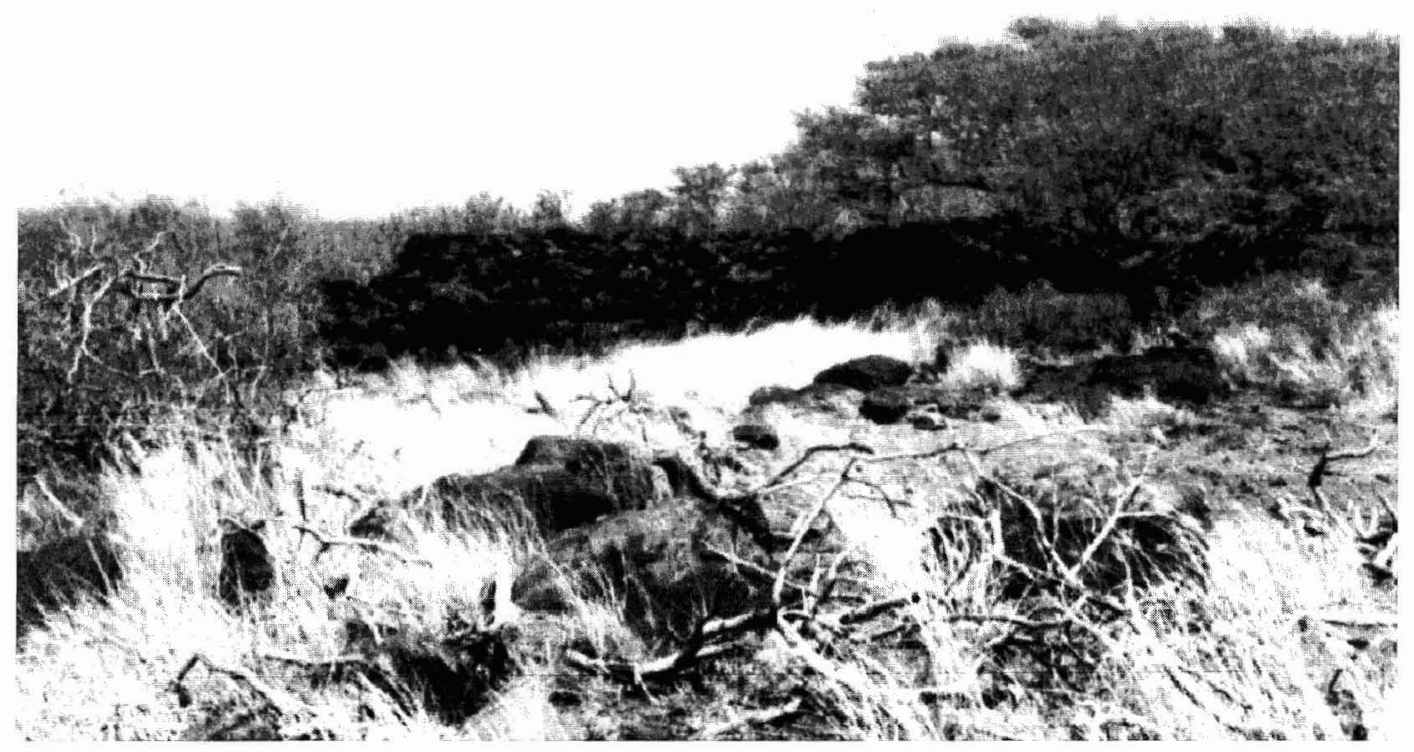

Figure 27b. Same location, 1993. Note the increase in grass and kiawe. 
TABLE 1

Extant Naturalized Alien Species Whose Introduction Predates the Ranching Era (1858-1941) Based on First-hand Reports

\begin{tabular}{llc}
\hline \hline Scientific Name & \multicolumn{1}{c}{ Common Name } & First Record on Kaho'olawe $^{a}$ \\
\hline Cenchrus echinatus & Common sandbur, 'ume 'alu & 1857 \\
Desmodium sandwicense & Spanish clover, pua pilipili & 1857 \\
Opuntia ficus-indica & Prickly pear, pānini, päpipi & 1854 \\
Soncbus oleraceous & Sow thistle, pualele & 1857 \\
\hline
\end{tabular}

a Warren et al. (1994).

the amount of vegetation, notable in almost all of the paired photographs. This expansion of vegetation cover can most likely be attributed to three primary factors. First, early increases in vegetation cover and diversity are attributable to the introduction of plants for livestock forage. Of particular note is kiawe. Referred to as algaroba in the early literature, kiawe was first reported on Kaho'olawe in 1904, at which time it was "already found there in large quantities ..." (Maui News 1904), although confined primarily to the lower slopes (Hosmer 1910b). Introduced to the state in 1828 , kiawe was widely used by the ranching industry during the early part of the twentieth century because the beans provide excellent forage (Hosaka and Ripperton 1944). The seeds are very hard and pass easily through the digestive tract of livestock, thus spreading the species quickly (Wagner et al. 1990). It is likely that the occurrence of kiawe on Kaho'olawe coincides with the introduction of domestic livestock (i.e., after 1859). Charles N. Forbes, former staff member at the Bishop Museum, placed the time of introduction at about 1898 (Forbes 1913). Today, kiawe is found over almost the entire island, even making inroads into sheltered areas on the eroded hardpan.

Only four naturalized alien species can be documented before the ranching era (Table 1). Numerous other species were introduced to Kaho'olawe during the ranching era ( $\mathrm{Ta}$ ble 2), including Australian saltbush (Atriplex semibaccata) (Ashdown 1979). The prostrate shrub is readily identifiable in Figure $16 b$. Between 1922 and 1929, at least a thousand pounds $[454 \mathrm{~kg}$ ] of Australian saltbush was planted in an effort to produce forage on the eroded hardpan of the upper plateau (Henke 1929, Ashdown 1979). Although unable to compete in grassy areas, Australian saltbush persists and provides a meager cover on much of the windswept hardpan.

The second factor contributing to increased vegetation was the elimination of livestock on Kaho'olawe. When the U.S. military subleased Kaho'olawe for training purposes, cattle and horses were removed. However, in the absence of on-site ranch hands to control them, the small bands of sheep and goats reproduced rapidly. In 1953, President Eisenhower issued an Executive Order requiring the Navy to eradicate all livestock from the island or limit their population to less than 200. Numerous hunting expeditions were successful in depressing the population, but with dense brush and many ravines providing hiding places for the sheep and goats, they were not eliminated. Attempts to eradicate the goats with poisoned alfalfa pellets were also unsuccessful (Honolulu Star-Bulletin 1970). Finally, a technique developed for the Hawai'i Volcanoes National Park for eradicating feral goats (Taylor and Katahira 1988) was adopted. Selected animals were radio-collared and released back into the resident population. Because goats and sheep are naturally gregarious, the collared animals quickly joined other groups. The collared animals were located periodically by helicopter using directional antennae and hand-held receivers. Any associated animals without collars were shot. The last of the feral animals were eliminated during the early 1990s. With the decimation of the sheep and 
TABLE 2

Extant Naturalized Alien Plant Species Whose Introduction to Kaho'olawe Can Be Reasonably Placed During the Ranching Era (1858-1941) Based on First-hand Reports and/or First Record in the State versus the First Record on Kaho'olawe

\begin{tabular}{|c|c|c|c|}
\hline Scientific Name & Common Name(s) & First Record in State ${ }^{a}$ & First Record on Kaho'olawe ${ }^{b}$ \\
\hline Agave sisalana & Century plant, sisal, malina & 1893 & 1913 \\
\hline Atriplex semibaccata & Australian saltbush & 1895 & 1922 \\
\hline Cajanus cajan & Pigeon pea, $p \bar{\imath} n \bar{u} n \bar{u}$ & 1864 & 1929 \\
\hline Casuarina equisetifolia & Common ironwood, paina & 1882 & 1940 \\
\hline Chamaesyce thymifolia & Spurge & 1871 & 1913 \\
\hline Chloris barbata & Swollen fingergrass, mau'u lei & 1902 & 1931 \\
\hline Desmodium triflorum & Three-flowered beggarweed & 1864 & 1913 \\
\hline Emilia coccinea & Flora's paintbrush & 1895 & 1931 \\
\hline Heterotbeca grandiflora & Telegraph weed & 1909 & 1931 \\
\hline Lantana camara & Läkana, lā'au kalakala & 1858 & 1913 \\
\hline Macroptilium latbyroides & Wild bean, cow pea & 1864 & 1931 \\
\hline Melinis minutiflora & Molasses grass & 1914 & 1940 \\
\hline Nicotiana glauca & Tree tobacco, mākāhala & 1864 & 1913 \\
\hline Panicum maximum & Guinea grass & 1871 & 1931 \\
\hline Paspalum dilatatum & Dallis grass & 1911 & 1916 \\
\hline Prosopis pallida & Mesquite, kiawe & 1828 & 1898 \\
\hline Rbynchelytrum repens & Natal redtop, Natal grass & 1903 & 1922 \\
\hline Tridax procumbens & Coat buttons & 1922 & 1931 \\
\hline Verbesina encelioides & Golden crown-beard & 1871 & 1931 \\
\hline $\begin{array}{l}\text { Xantbium strumarium } \\
\text { var. canadense }\end{array}$ & Cocklebur, kīkānia & 1871 & 1931 \\
\hline
\end{tabular}

${ }^{a}$ Wagner et al. (1990).

${ }^{b}$ Warren et al. (1994).

goat populations, the vegetation, both native and introduced, has begun to show remarkable recovery. Some of the more notable increases in herbaceous ground cover are visible in Figures 5, 9, 13, 14, and 27. 'Ilima (Sida fallax), an indigenous species not present in the 1931 photographs, is now visible in Figure $3 b$. In 1931, only 60 species of native or naturalized plants had been recorded on Kaho'olawe (Warren et al. 1994). Botanical surveys in 1978, 1980, and 1992 revealed 32, 36 , and 20 additional native and naturalized species, respectively (Department of the Navy 1979, Corn et al. 1980, Hawaii Heritage Program, The Nature Conservancy of Hawai'i 1992 , respectively).

The third primary factor contributing to the increase in vegetation on Kaho'olawe during the military era has been the revegetation and erosion control efforts. Between 1971 and 1973, the U.S. Forest Service, in cooperation with the Hawai' $i$ Division of Forestry and the Soil Conservation Service, successfully introduced or reintroduced approximately 60 species to Kaho'olawe (Whitesell et al. 1971, 1973). Many have since died out, although others persist and some have become naturalized. Beginning in 1978, the State Department of Land and Natural Resources began planting rows of tamarisk (Tamarix apbylla) and ironwood (Casuarina equisetifolia) as windbreaks across large stretches of the higher-elevation hardpan (Pacific Division, Naval Facilities Engineering Command 1989). Many of the windbreaks are now well-established (Figure 14b). A cooperative effort between the Navy and the Native Hawaiian Plant Society between 1985 and 1989 resulted in the planting of more than 23,000 native plants, comprising nearly 40 native species (Pacific Division, Naval Facilities Engineering Command 1989). Under a project funded by the Navy, the U.S. Army Construction Engineering 
TABLE 3

Extant Alien Plant Species Whose Introduction to Kaho'olawe Can Be Definitively Linked to Post-ranching Restoration Efforts Based on First-hand Reports

\begin{tabular}{llc}
\hline \hline Scientific Name & Common Name(s) & First Record on Kaho'olawe $^{a}$ \\
\hline Acacia confusa & Formosa koa & 1971 \\
Acacia implexa & Twisted wattle & 1971 \\
Botbriocbloa ischaemum & Yellow bluestem & 1993 \\
Bucbloe dactyloides & Buffalograss & 1993 \\
Casuarina glauca & Longleaf ironwood & 1973 \\
Cenchrus ciliaris & Buffelgrass & 1971 \\
Cupressus sempervirens & Mediterranean cypress & 1971 \\
Cynodon plectostachyus & Starrgrass & 1971 \\
Digitaria eriantba & Fingergrass & 1973 \\
Digitaria pentzii & Pangola grass & 1971 \\
Eragrostis curvula & Weeping lovegrass & 1973 \\
Eragrostis supurba & Lovegrass & 1973 \\
Eucalyptus camaldulensis & Red river gum & 1971 \\
Eucalyptus citriodora & Lemon-scented gum & 1971 \\
Eucalyptus punctata & Grey gum & 1973 \\
Eucalyptus sideroxylon & Red ironbark, mugga & 1971 \\
Glycine wigbtii & Glycine & 1971 \\
Lolium multiflorum & Italian ryegrass & 1993 \\
Macroptilium atropurpureum & Siratro & 1993 \\
Nerium indicum & Oleander & 1971 \\
Setaria leucopila & Plains bristlegrass & 1993 \\
Tamarix apbylla & Tamarisk & 1971
\end{tabular}

${ }^{a}$ Warren et al. (1994).

Research Laboratory developed and implemented a land rehabilitation prescription on an 8-ha watershed, introducing five additional alien species (Warren and Aschmann 1993, Ziegler et al. 2000). The Protect Kaho'olawe 'Ohana and the University of Hawai'i have also participated in various native plantings (Pacific Division, Naval Facilities Engineering Command 1989). In all, approximately 69 species previously unrecorded on Kaho'olawe, including 19 that are native to the Hawaiian Islands, have been intentionally introduced to the island since 1971 (Warren et al. 1994). Approximately 22 alien species are thought to persist (Table 3).

The residual impacts of military usage on the Kaho'olawe landscape are only minimally apparent in the photographs from the 1990s. Barrels marking an abandoned target are seen in Figure $5 b$. More recent targets, painted white, are visible in Figures $9 b$ and 13b. Remnants of military ordnance are also present in Figure 11b. The apparent absence of artifacts in the recent photographs is not representative of the island as a whole; military debris, including targets and exploded and unexploded ordnance, was present in the early 1990s in locations not covered by Bryan and McAllister in the 1930s. Much of the accumulation of debris has since been removed as part of the Navy's cleanup program.

Bombardment of the island during the era of military occupation undoubtedly contributed to the extensive erosion initiated during the premilitary era. Depending on ambient wind speeds, soil particles thrown into the air as a result of explosions are immediately susceptible to wind erosion. Soil particles loosened by exploding ordnance continue to be subject to the erosive forces of both wind and water for weeks or months. Erosion of the upper reaches of the island is evident by the presence of alluvial fans of eroded sediment on the beaches at Papakanui Bay (Figure 19) and Hakioawa (Figure 26) in the 1930s and 1990s. Not all of the military impacts are 


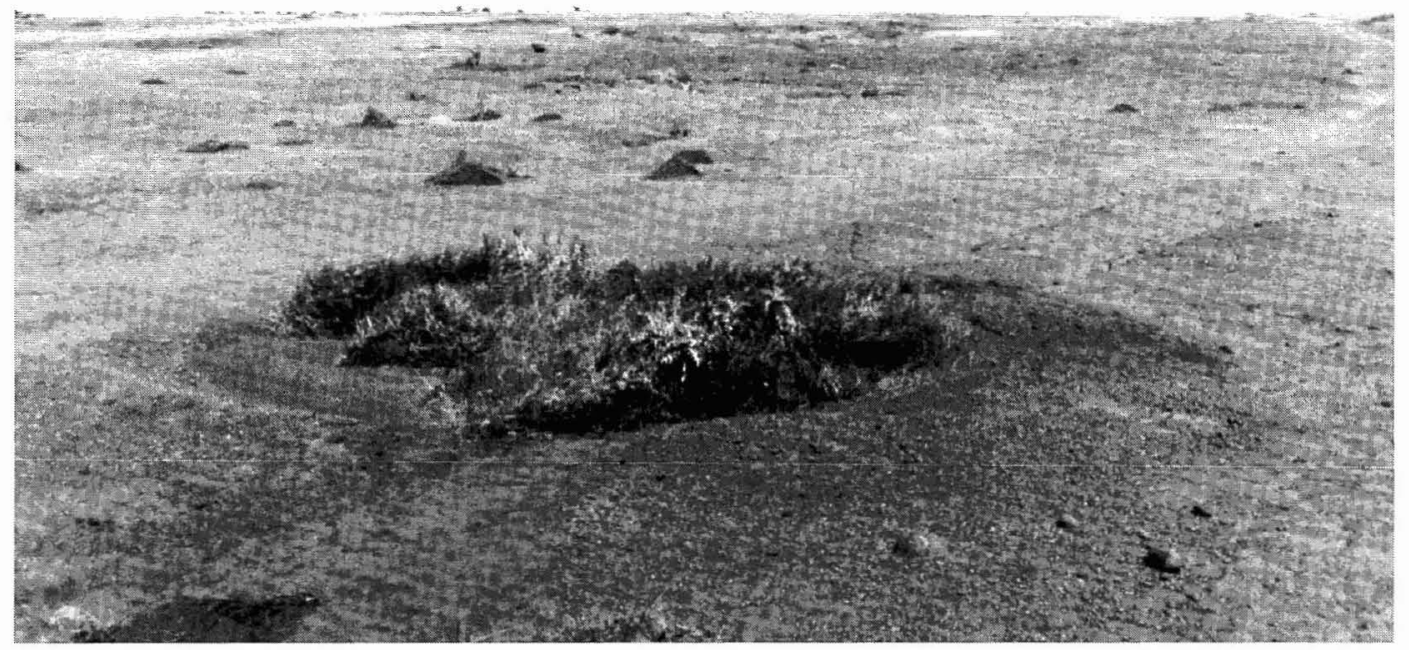

FIGURE 28. Crater formed by exploding ordnance. Note the amount of vegetation inside versus outside the crater.

negative, however. Craters resulting from explosions form microcatchments that accumulate runoff and windblown soil particles, thus providing suitable habitat for plants on the otherwise denuded hardpan (Figure 28). Fires resulting from ordnance explosions and flares have been beneficial for maintaining the extensive piligrass (Heteropogon contortus) population on Kaho'olawe, because fire promotes both seed production and seedling recruitment of this important native species (Orr et al. 1991).

It is evident from the paired photographs that the condition of Kaho'olawe improved markedly between the 1930s and the 1990s. Although military training activities exacted an environmental toll on the island, conservation efforts including the goat control program and the various planting efforts more than compensated for the negative impacts. There are no longer reports of great clouds of red dust blowing off the island. And barring the recurrence of environmentally deleterious activities, it is likely that the recovery of Kaho'olawe will continue.

\section{Literature Cited}

Allen, W. F. 1858. Correspondence to R. C. Wyllie dated 31 May. On file at Hawai'i State Archives, R. C. Wyllie Private Collection, Honolulu.

Ashdown, I. M. 1979. Recollections of Kaho'olawe. Topgallant, Honolulu.

Bagot, F., ed. 1884. McKenney's Hawaiian directory. L. M. McKenney \& Co., San Francisco.

Beaglehole, J. C., ed. 1967. The journals of Captain James Cook on his voyage of discovery. III. The voyage of the Resolution and Discovery 1776-1780. University Press, Cambridge.

Bowser, G., ed. 1880. The Hawaiian Kingdom statistical and commercial directory and tourists' guide, 1880-1881. George Bowser \& Co., Honolulu.

Corn, C. A., W. Char, G. Clarke, and L. W. Cuddihy. 1980. Kaho'olawe botanical survey (April 21-25, 1980). Division of Forestry, Department of Land and Natural Resources, State of Hawai'i, Honolulu. 
Cuddihy, L. W., and C. P. Stone. 1990. Alteration of native Hawaiian vegetation. University of Hawai' $i$ Cooperative $\mathrm{Na}$ tional Park Resources Study Unit, Honolulu.

Department of Geography, University of Hawaici. 1973. Atlas of Hawaii. University Press of Hawai'i, Honolulu.

Department of the Navy. 1979. Environmental impact statement: Military use of Kahoolawe training area. Prepared by Environmental Impact Study Corp., Honolulu.

Forbes, C. N. 1913. Notes on the flora of Kahoolawe and Molokini. Occas. Pap. Bernice Pauahi Bishop Mus. 4.

Hawai'i Heritage Program, The Nature Conservancy of Hawai'i. 1992. Biological database and reconnaissance survey of Kaho'olawe Island including rare plants, animals, and natural communities. Prepared for the Kaho'olawe Island Conveyance Commission, Wailuku, Maui.

Hawaiian Gazette. 1881. A great change is coming over Kahoolawe. 17 August.

- 1918a. Want Kahoolawe for cattle range-Effort to be made to have island turned over for grazing-Would solve beef problem. 5 April.

-1918b. Goats of Kahoolawe must go, is order. 26 April.

Henke, L. A. 1929. A survey of livestock in Hawaii. Univ. Hawaii Res. Publ. 5.

Hommon, R. J. 1980. Historic resources of Kaho'olawe. National Register of Historic Places Inventory-Nomination Form. U.S. Navy, Pacific Division, Naval Facilities Engineering Command, Pearl Harbor, Honolulu.

Honolulu Star-Bulletin. 1970. Goats stubborn, refuse to die. 11 June.

Hosaka, E. Y., and J. C. Ripperton. 1944. Legumes of the Hawaiian ranges. Hawaii Agric. Exp. Stn. Bull. 93.

Hosmer, R. S. 1910a. Kahoolawe Forest Reserve. Hawaiian For. Agric. 8 (9): 264267.

- 1910b. Forest reserve hearing. Hawaiian For. Agric. 8 (9): 267-271.

Judd, H. P. 1938. A visit to Kahoolawe. Paradise of the Pacific. October: 11-12.
Ka Lahui Hawaii. 1875. Ka Huakai Alii A Kalani Moi Davida Kalakaua Ma Na Hono A Piilani (The Royal Excursion of His Royal Highness David Kalakaua to the Bays of Piilani). 30 December.

Kirch, P. V. 1982. The impact of the prehistoric Polynesians on the Hawaiian ecosystem. Pac. Sci. 36:1-14.

Lomax, A. L. 1940. Geographic factors in early sheep husbandry in the Hawaiian Islands (1791-1870). 48th Annual Report of the Hawaiian Historical Society, for the year 1939. Honolulu.

Maui News. 1904. Kahoolawe to the front. 16 January.

McAllister, J. G. 1933. Archaeology of Kahoolawe. Bernice P. Bishop Mus. Bull. 115.

Mueller-Dombois, D., and F. R. Fosberg. 1998. Vegetation of the tropical Pacific islands. Springer-Verlag, New York.

Orr, D. M., G. M. McKeon, and K. A. Day. 1991. Burning and exclosure can rehabilitate degraded black speargrass (Heteropogon contortus) pastures. Trop. Grassl. 25:333-336.

Pacific Division, Naval Facilities Engineering Command. 1989. Conservation plan for Kaho'olawe Island, Hawaii. Report prepared for Commander Naval Base, Pearl Harbor, Honolulu.

Perkins, E. T. 1854. Na Motu, or reefrovings in the South Seas. Pudney \& Russell, New York.

Rice, H. W., O. L. Sorenson, and R. Hind. 1932. Inspection and land re-appraisal report submitted to R. C. Brown, Acting Governor of Hawaii. On file at State Land Management Office, Land Records and Correspondence, Honolulu.

Stearns, H. T. 1940. Geology and groundwater resources of the islands of Lanai and Kahoolawe, Hawaii. Territ. Hawaii, Div. Hydrogr. Bull. 6.

Sunday Advertiser. 1912. Kahoolawe the island that is wearing out-A problem solved. 14 January.

Taylor, D., and L. Katahira. 1988. Radio telemetry as an aid in eradicating remnant feral goats. Wildl. Soc. Bull. 16:297299. 
Vancouver, G. 1798. A voyage of discovery to the North Pacific Ocean, and round the world. (1967 reproduction of the original edition). Da Capo Press, New York.

Wagner, W. L., D. R. Herbst, and S. H. Sohmer. 1990. Manual of the flowering plants of Hawai'i. 2 vols. University of Hawai'i Press and Bishop Museum Press, Honolulu.

Warren, S. D., and S. G. Aschmann. 1993. Revegetation strategies for Kaho'olawe Island, Hawaii. J. Range Manage. 46:462466.

Warren, S. D., S. G. Aschmann, and D. R. Herbst. 1994. The plants of Kaho'olawe. U.S. Army Construction Engineering Research Laboratories Spec. Rep. EN-94/05. Champaign, Illinois.

Whitesell, C. D., D. N. Palmer, and H. K. Yanamura. 1971. Study plan and establishment report for vegetation trials for rehabilitating Kahoolawe Island, Hawaii. U.S. Forest Service, Pacific Southwest Forest and Range Experiment Station. On file at the Institute of Pacific Islands Forestry, Honolulu.

Whitesell, C. D., W. H. C. Wong Jr., and D. N. Palmer. 1973. Establishment report no. 2 for vegetation trials for rehabilitating Kahoolawe, Island, Hawaii. U.S. Forest Service, Pacific Southwest Forest and Range Experiment Station. On file at the Institute of Pacific Islands Forestry, Honolulu.

Wilkes, C. 1845. Narrative of the United States' Exploring Expedition, during the years 1838, 1839, 1840, 1841, 1942. Whittaker \& Co., London, England.

Ziegler, A. D., and T. W. Giambelluca. 1998. Influence of revegetation efforts on hydrologic response and erosion, Kaho'olawe Island, Hawai'i. Land Degrad. Develop. 9:189-206.

Ziegler, A. D., S. D. Warren, J. L. Perry, and T. W. Giambelluca. 2000. Reassessment of revegetation strategies for Kaho'olawe Island, Hawai'i. J. Range Manage. 53:106113. 